\title{
Açık-Düşündürücü Yaklaşıma Dayalı Etkinliklerin Ortaokul Öğrencilerinin Bilimin Doğası Görüşlerine Etkisi
}

\section{The Effects of Explicit-Reflective Approach Based Activities on Middle School Students' Nature of Science Views}

\author{
Ertan ÇETINKAYA*
}

Received: 21 January 2018

Research Article

Accepted: 20 November 2018

ABSTRACT: The aim of this research is to examine the effect of nature of science (NOS) activities related science content based on explicit-reflective approach on 6th grade students. The study group consisted of 50 students studying in a public school in İstanbul. In this research pretest-posttest control group experimental design has been used. In the "Systems in our Body" unit, for the experimental group teaching NOS was carried out using the explicitreflective approach through the activities developed by Yalaki (2016). The methods and techniques suggested by the teaching program were used for the control group. The data were collected through the VNOS-D+ questionnaire. Analysis of the research data was carried out in two stages. In the first stage, the data were analyzed by content analysis. In the second stage, student responses were scored by dividing into 3 categories by a rubric developed by Yalaki and Çakmakçı (2011). The findings of this research reveal that the explicit-reflective approach does not make a significant difference in the 6th grade students' views on the nature of science. The instruction has provided meaningful difference in the tentative nature of science, while it didn't make any change in the subjective, creative and empirical nature of science.

Keywords: Nature of science, middle school students, bidomeg.

ÖZ: Bu araştırmada, açık-düşündürücü yaklaşıma dayalı konu alanı ile ilişkili bilimin doğası etkinliklerinin ortaokul 6. sınıf öğrencilerinin bilimin doğası görüşlerine etkisini incelemek amaçlanmıştır. Çalışma grubunu İstanbul'da bir devlet okulunda öğrenim gören 50 öğrencinin oluşturduğu bu araştırmada, ön-test son-test kontrol gruplu desen kullanılmıştır. "Vücudumuzdaki Sistemler" ünitesinde bilimin doğası öğretimi deney grubuna Yalaki (2016) tarafından geliştirilen etkinlikler ile açık-düşündürücü yaklaşımla, kontrol grubuna ise öğretim programının önerdiği yöntem ve teknikler kullanılarak dolaylı biçimde gerçekleştirilmiştir. Araştırma verileri VNOS-D+ formu kullanılarak toplanmıştır. Araştırma verilerinin analizi iki aşamada gerçekleştirilmiştir. Birinci aşamada veriler içerik analizi ile incelenmiş, ikinci aşamada ise öğrenci yanıtları Yalaki ve Çakmakçı (2011) tarafından geliştirilen dereceli puanlama anahtarı ile 3 kategoriye ayrılarak puanlanmıştır. Elde edilen puanlar istatistiksel analizde kullanılmıştır. Araştırma sonuçları etkinliklerin 6. sınıf öğrencilerinin bilimin doğası görüşlerinde anlamlı bir değişim oluşturmadığını göstermiştir. Etkinlikler bilimin ampirik doğası, bilimin subjektif doğası ve bilimin yaratıcı doğasında bir değişiklik oluşturmazken, bilimin değişken doğasında anlamlı bir değişim sağlamıştır.

Anahtar kelimeler: Bilimin doğası, ortaokul öğrencileri, bidomeg.

* Dr, Ministry of National Education, Istanbul, Turkey, ertancetinkayaa@ gmail.com

Citation Information

Çetinkaya, E. (2019). Açık-düşündürücü yaklaşıma dayalı etkinliklerin ortaokul öğrencilerinin bilimin doğası görüşlerine etkisi. Kuramsal Eğitimbilim Dergisi [Journal of Theoretical Educational Science], 12(1), 227-259. 


\section{Giriş}

Bilimsel okuryazarlığın öğrencilere kazandırılması fen eğitiminin uzun süreli hedefleri arasında yer almaktadır (Khishfe \& Lederman, 2006). Son y1llarda fen eğitimi reform hareketlerine ilişkin yayınlanan dokümanlar temel amaç olarak bilimsel okuryazarlığa odaklanmaktadır (Next Generation Science Standarts [NGSS] Lead States, 2013; National Research Council [NRC], 1996; Milli Eğitim Bakanlığ1 [MEB], 2017). Perspektifleri birbirinden farklı olmasına karşın reform önerilerinde bilimin doğasına yapılan güçlü vurgu dikkat çekmektedir (Lederman, 1999). Eğitim reform dokümanları öğrencilerin bilimsel okuryazarlık düzeyini arttırmak için bilimin doğası öğretiminin gerekli olduğunu ifade etmektedir (American Association for the Advancement of Science [AAAS], 1990; Council of Ministers of Education Canada [CMEC], 1997; NRC, 2012).

Bilimin doğası kavramı ilk olarak 20. yüzyıl başlarında lise biyoloji derslerinde kullanılması gereken ilkelerin tartışıldığı bir toplantıda dile getirilmiştir. Toplantıda bilimin doğasını anlamanın bilimsel yöntemi anlamakla eşdeğer olduğu ifade edilmiştir (Central Association for Science and Mathematics Teachers [CASMT], 1909). Yillar içinde bilimin doğasının odak noktası önce bilimsel süreçler ile araştırma ve sorgulamaya, daha sonra bilimin değişkenliğine, hümanistik doğasına, holistik ve ampirik yapısına kaymıştır (Abd-El-Khalick \& Lederman, 2000a). Bilimin doğası bugün bilim epistemolojisi, bir bilme biçimi olarak bilim ya da bilimsel bilginin gelişimine özgü değerler ve inançları işaret etmektedir (Lederman, 1992). Çizilen bu çerçeveye karşın bilim insanlarının üzerinde uzlaştıkları tek bir bilimin doğası tanımı bulunmamaktadır. Ancak bilimin doğasında yer alan unsurlar üzerinde bir uzlaşıdan söz etmek mümkündür (McComas \& Olson, 2002).

Bilimin değişken doğası, ampirik doğası, subjektifliği, hayal gücü ve yaratıcılık ürünü oluşu, sosyal ve kültürel unsurlardan etkilenmesi, çıkarım ile gözlem arasındaki farklılıklar ve teori ile kanun arasındaki ilişki gibi boyutlar bilim insanlarının, eğitim felsefecilerinin ve sosyologlarının uzlaşı sağladığı bilimin doğası unsurlarıdır (Abd-ElKhalick \& Akerson, 2004; Khishfe \& Lederman, 2006). Bahsi geçen bilimin doğas1 unsurlarının kazandırılması bilimsel okuryazar bireyler yetiştirmek için bir önkoşul olarak görülebilir. Bu nedenle öğrencilerin bilimin doğası anlayışlarının geliştirilmesi fen eğitiminin önemli bir parçası olmuştur (Kang, Scharmann, \& Noh, 2005; Khishfe \& Abd-el-Khalick, 2002). Bu girişimlere rağmen yürütülen araştırmalar öğrencilerin bilimin doğası anlayışlarının yetersiz düzeyde olduğunu ortaya koymaktadır (Khishfe, 2008; Liu \& Lederman, 2002; Walls, 2012; Yacoubian \& BouJaoude, 2010).

Bilimsel içeriğe ve bilimin doğasının boyutlarına yönelik derin bir anlayış kazanmak fen eğitimine ilişkin diğer hedeflere ulaşmak için de son derece önemlidir (Herman, 2010). Bahsedilen türde bir anlayış geliştirmek için de bilimin doğasının etkili bir biçimde öğretilmesi gerekmektedir. Bilimin doğasının tanımında olduğu gibi bilimin doğasının nasıl öğretileceğine ilişkin de alanyazında farklı görüşler bulunmaktadır. Geçmişte bilimin doğası öğretimi için tarihsel ve dolaylı yaklaşımın alanda kendine yer bulduğu ve 2000'li y1llara gelinirken bir alternatif olarak doğrudan yaklaşımın da ön plana çıkmaya başladığı görülmektedir (Lederman, 1998). Çok geçmeden bilimin doğası öğretimi literatürünü eleştirel biçimde inceleyen Abd-El-Khalick ve Lederman (2000a) doğrudan yaklaşımı, dolaylı yaklaşım ile birlikte iki temel öğretim 
yaklaşımından biri olarak sınıflamıştır. Bazı çalışmalar (Abd-El-Khalick \& Akerson, 2004; Abd-El-Khalick \& Lederman, 2000b; Schwartz \& Crawford, 2004, ss.333-336; Lederman, 2007; Özgelen, 2010) bilimin doğası öğretiminde doğrudan ve dolaylı olmak üzere sadece iki yaklaşımdan söz ederken, bazı araştırmalar (Gess-Newsome, 2002; Khishfe \& Abd-El-Khalick, 2002; Köseoğlu, Tümay, \& Budak, 2008; Yücel-Dağ, 2015) ek olarak tarihsel yaklaşımın da bilimin doğası öğretiminde yer alan bir öğretim stratejisi olduğunu dile getirmektedir. Buna karşın bilimin doğası öğretiminde son yıllarda bilim tarihi ögelerinin sosyo-bilimsel konular ve araştırma-sorgulama yaklaşımı gibi bir bağlam olarak kullanıldığı görülmektedir (Khishfe, 2015; Fouad, Masters, \& Akerson, 2015).

Dolaylı öğretim yaklaşımında bireylerin bilimsel süreçleri izleyerek bilimin doğasına yönelik çıkarımlar yapabilecekleri ve bilimin doğası anlayışlarının gelişeceği bir öğretim süreci hedeflenmektedir (Çetinkaya, 2012). Dolaylı yaklaşımda öğrencilerin bilim yaparken bilimin doğası anlayışlarının gelişmesi beklenmektedir (Köseoğlu, Tümay, \& Budak, 2008). Doğrudan yaklaşımda öğrencilere bilimin doğası anlayışının kazandırılması öğretim sürecinin ikincil bir ürünü veya bir yan etkisi olarak değil, aksine öğretim sürecinin planlanması ile ulaşılabilecek bir hedef olarak görülmektedir (Akindehin, 1988). Bu yaklaşımda öğrencilerin dikkati tartışmalar ve sorular yolu ile bilimin doğası boyutlarına çekilir (Adıbelli-Şahin \& Deniz, 2017). Tarihsel yaklaşımda ise bilim tarihi ögelerinin fen öğretim sürecine entegre edilmesi ile öğrencilerin sahip oldukları bilimin doğası görüşlerinin iyileştirilebileceği savunulmaktadır (Lederman, 1998).

Bilimin doğası öğretim stratejilerinde kısa zaman içinde çeşitli paradigma değişimleri meydana gelmiştir. Doğrudan öğretim yaklaşımına ek olarak düşündürücü bileşenlerin de sürece dâhil edilmesinin etkililiği araştırılmış ve düşündürücü ögelerin kullanılmasının bilimin doğası öğretiminde daha etkili olduğu bulgusuna ulaşılmıştır (Dickinson, Abd-El-Khalick, \& Lederman, 2000). Öğretim stratejilerindeki bu gelişmelerin ardından doğrudan yaklaşıma düşündürücü bileşenler entegre edilmiş ve bu yaklaşım doğrudan-yansıtıcı ya da açık-düşündürücü yaklaşım olarak isimlendirilmeye başlanmıştır.

Bilimin doğası öğretim yaklaşımlarına yönelik araştırmalar zaman içinde hangi yaklaşımın daha etkili olduğu sorusu etrafında şekillenmeye başlamıştır. Bu dönemde Khishfe ve Abd-El-Khalick (2002) öğretim stratejilerinin etkililiğini sinayan bir karşılaştırma çalışması gerçekleştirilmiş ve açık-düşündürücü yaklaşımın dolaylı yaklaşıma göre daha etkili olduğu sonucuna ulaşılmıştır. Bu tarihten sonra bilimin doğası anlayışlarını geliştirmeye odaklanan çalışmaların birçoğu öğretim stratejisi olarak açık-düşündürücü yaklaşımı merkeze almıştır. Yapılan araştırmaların önemli bir bölümü açık-düşündürücü öğretim stratejisinin bilimin doğası öğretiminde etkili bir yaklaşım olduğunu ortaya koymaktadır (Abd-El-Khalick, 2005; Ağlarcı, Sarıçayır, \& Şahin, 2016; Erdoğan \& Köseoğlu, 2015; Khishfe \& Lederman, 2006; Koenig, Schen, \& Bao, 2012; Önen-Öztürk, 2015; Wong, Firestone, Ronduen, \& Bang, 2016). Buna karşın araştırmaların bir kısmı da bu yaklaşımın öğrencilerin bilimin doğası anlayışlarını geliştirmediğini ya da bu anlayışlarda sınırlı bir değişime neden olduğunu dile getirmektedir (Liu \& Lederman, 2002; Morrison, Raab, \& Ingram, 2009). Açıkdüşündürücü yaklaşımın öğretim stratejisi olarak kullanıldığı çalışmalarda bu yaklaşımın bilimin doğasının bazı boyutlarında yeterince etkili olmadığı dikkat 
çekmektedir. Özellikle teori ile kanun arasındaki ilişkinin, süreç içerisinde doğrudan vurgulanmasına karşın öğrenciler tarafından yeterince anlaşılamadığı bu çalışmaların (Ağlarc1, 2014; Küçük, 2006; 2008) önemli bulgularındandır.

Dolaylı yaklaşım kullanılarak gerçekleştirilen öğretimin etkililiğine ilişkin literatürde birbirinden farklı, uç noktalarda sonuçlar bulmak mümkündür. Bell, Blair, Crawford ve Lederman (2003) yürüttükleri araştırmada dolaylı yaklaşımın öğrencilerin bilimin doğası anlayışında herhangi bir değişikliğe yol açmadığı sonucuna ulaşmışlardır. Ryder, Leach ve Driver (1999), Cengiz ve Kabapınar (2017) ile Ayvacı (2007) bu yaklaşımın öğrencilerin bilimin doğası anlayışlarında kısıtlı değişim oluşturduğunu ve sadece belli boyutlarda gelişim sağladığını ifade etmişlerdir. Barab ve Hay (2001) ile Salter ve Atkins (2013) ise dolaylı yaklaşımın öğrencilerin bilimin doğası anlayışlarında gelişim sağladığı bulgusuna ulaşmışlardır.

Ülkemizde ise bilimin doğası çalışmaları son yıllarda ivme kazanmıştır (Çil \& Çepni, 2016; Doğanay, Demircioğlu, \& Yeşilpınar, 2014; Göksu, Aslan, Özel, \& ŞenelZor, 2016; Hastürk, Öztürk, Demir, \& Kartal, 2014; Karakaş, 2017; Özden \& Yenice, 2016; Yenice, Özden, \& Balc1, 2015). Gerçekleştirilen çalışmaların bir bölümü öğrencilerin bilimin doğası anlayışlarını tespit etmeyi amaçlarken (Adak \& Bakır, 2017; Aslan \& Taşar, 2013; Hastürk, Öztürk, Demir, \& Kartal, 2014; İflazoğlu-Saban \& Saban, 2014), bir bölümü de öğretim programlarında bilimin doğasının durumunu incelemeye odaklanmıştır (Özden \& Cavlazoğlu, 2015; Şardağ, Aydın, Kalender, Tortumlu, Çiftçi, \& Perihanoğlu, 2014). Ülkemizde gerçekleştirilen çalışmalarda öğrencilerin bilimin doğası anlayışlarını geliştirmek için açık-düşündürücü yaklaşım kullanan araştırmaların çalışma gruplarını öğretmen adaylarının oluşturduğu görülmüştür (Çelik, 2015; Erdoğan \& Köseoğlu, 2015; Önen-Öztürk \& Bayram, 2017). Açık-düşündürücü yaklaşım kullanılarak ortaokul öğrencileri ile yürütülen bir çalışmada (Çokadar \& Demirtel, 2012) ise gerçekleştirilen öğretim uygulamalarının konu alanından bağımsız, derse entegre edilmemiş bir biçimde uygulandığı saptanmıştır. Alanyazın incelendiğinde bilimin doğası çalışmalarının önemli bir bölümünün öğretmen ve öğretmen adayları ile gerçekleştirildiği görülmektedir. Buna karşın daha küçük yaşlardaki bireylerin bilimin doğasını anlayışlarını yansıtacak çalışma sayısının azlığı dikkat çekmektedir. Bilişsel gelişim aşamaları incelendiğinde ortaokul yıllarından itibaren öğrencilerin farklı bir bilişsel aşamaya geçtikleri açığa çıkmaktadır. Özellikle 11 yaşlarından itibaren çocukların soyut işlemler dönemine girdikleri ve bu yaşlarda muhakeme becerisi kazandikları ifade edilmektedir (Piaget, 2006, s. 105). Buradan hareketle bireysel farklılıklar olsa da soyut işlemler döneminin başlangıcında olan bireylerin bilimin doğası boyutlarına ilişkin bilgi düzeyleri ve bunların gelişimi önemli bir noktada konumlanmaktadır. Bu nedenle ortaokul öğrencilerinin bilimin doğas1 anlayışlarını geliştirecek konu alanı ile ilişkili açık-düşündürücü öğretim yaklaşımı kullanılan uygulamaların etkililiğinin açığa çıkarılmasına ihtiyaç olduğu düşünülmektedir. Bu ihtiyacı karşılamak amacıyla öğretim programının ortaokul 6. sınıf öğrencileri için önerdiği ilk ünite olan "Vücudumuzdaki Sistemler" ünitesinde derse entegre etkinlikler kullanarak alana katkı sağlanabileceği düşünülmektedir. Mevcut çalışmada ortaokul öğrencilerinin bilimin doğası anlayışlarının açığa çıkarılması ve konu alanı ile ilişkili etkinliklerin açık-düşündürücü öğretim yaklaşımıyla uygulanmasının ortaokul öğrencilerin bilimin doğası anlayışlarına etkisinin saptanması amaçlanmıştır. Bu doğrultuda "Vücudumuzdaki Sistemler ünitesinde uygulanan derse 
entegre açık-düşündürücü yaklaşıma dayalı etkinliklerin ortaokul 6. sınıf öğrencilerin bilimin doğası ve bilimin doğasının alt boyutlarına ilişkin görüşlerine bir etkisi var mıdır?" sorusu araştırmanın problem cümlesini oluşturmaktadır.

\section{Yöntem}

\section{Araştırma Deseni}

$\mathrm{Bu}$ çalışmada ön-test son-test eşleştirilmiş kontrol gruplu yarı-deneysel desen kullanılmıştır. Yarı-deneysel desenlerde, araştırmaya katılacak kişilerin seçiminde rastgelelik görülmez (Fraenkel, Wallen, \& Hyun, 2011, s. 275). Bunun yerine araştırmacı, araştırmada yer alacak kontrol ve deney gruplarının belirli değişkenler açısından eşleştirilmiş olması gereken birden fazla desene başvurulabilir. $\mathrm{Bu}$ desenlerden biri olan ön-test son-test eşleştirilmiş kontrol gruplu desendir. Bahsi geçen desende araştırmada yer alacak iki grup bazı değişkenler açısından eşleştirilmeye çalışılır ve bu iki grup yapılacak uygulamada kontrol ve deney gruplarına rastgele atanırlar (Büyüköztürk, Çakmak, Akgün, Karadeniz, ve Demirel, 2009, s. 208). Bu araştırmada da araştırmaya katılacak iki grup, araştırmanın bağımlı değişkeni olan bilimin doğası görüşleri açısından eşitlenmeye çalışılmıştır. Bu doğrultuda uygulama yapılacak okulda yer alan 6. sınıflar arasından iki şube seçilmiş ve bu grupların bilimin doğası görüşlerini ölçen ön-test puanlarının eşit olması kontrol edilmiştir. Bunun ardından araştırmanın yapılacağı şubeler rastgele kontrol ve deney gruplarına atanmıştır. Ardından gruplara öğretim etkinlikleri uygulanmıştır. Öğrencilere yönelik uygulanan öğretim etkinliklerinden sonra aynı veri toplama aracı bu kez son-test olarak uygulanmıştır. Elde edilen verilerin karşılaştırılması ile öğretim sürecinde kullanılan etkinliklerin bilimin doğası görüşleri üzerindeki etkisi belirlenmiştir.

\section{Çalışma Grubu}

Araştırma 2017-2018 eğitim-öğretim y1lı güz döneminde İstanbul'daki bir devlet ortaokulunun 6. sınıfinda öğrenim görmekte olan 50 öğrenci ile yürütülmüştür. Araştırma kapsamında seçkisiz biçimde deney ve kontrol grupları belirlenmiştir. Basit seçkisiz örnekleme; her bir örneklem birimine eşit seçilme olasıllğ 1 verildiği durumlarda kullanılır (Çıngı, 1994). Araştırmacının öğretmen olarak görev yaptığı ve dersine girdiği iki şubeden birisi deney grubu, diğeri ise kontrol grubu olarak belirlenerek uygulamalar araştırmacı tarafından gerçekleştirilmiştir.

Tablo 1

Katılımcıların Cinsiyet ve Gruplara Göre Dă̆ılımları

\begin{tabular}{cccc}
\hline & Erkek öğrenci & Kı̈ öğrenci & Toplam \\
\hline Deney grubu & 14 & 14 & 28 \\
Kontrol grubu & 11 & 11 & 22 \\
\hline Toplam & 25 & 25 & 50 \\
\hline
\end{tabular}

Araştırmaya katılan öğrencilerin 28'i deney grubunda, 22'si ise kontrol grubunda bulunduğu Tablo 1'den anlaşılmaktadır. Öğrencilerin cinsiyetlerine göre dağılımları incelendiğinde; deney grubunda yer alan öğrencilerin 14'ünün erkek, kalan 
14'ünün ise kız olduğu görülmektedir. Kontrol grubundaki öğrencilerin 11'inin erkek, kalan 11'inin ise kız olduğu görülmektedir. Öğrenci sayıları bir bütün olarak incelendiğinde araştırmaya katılan 50 öğrencinin 25'inin erkek, 25'inin ise kız olduğu görülmektedir.

\section{Veri Toplama Araçları}

Öğrencilerin bilimin doğası görüşlerini ve öğretim süreci içinde bu görüşlerdeki değişimi belirlemek amacıyla Lederman ve Khishfe (2002) tarafından geliştirilen Bilimin Doğası Görüşleri Anketi - Form D+ (VNOS-D+) kullanılmıştır. Bilimin Doğası Görüşleri Anketi (VNOS) farklı zamanlarda geliştirilmiş, farklı yaş ve eğitim gruplarını hedefleyen beş formdan oluşmaktadır. Mevcut araştırmada çalışma grubu olarak ortaokul öğrencilerini hedefleyen ve bu öğrencilerin bilimin doğasına ilişskin anlayışları ölçmeyi amaçlayan VNOS- Form D+ kullanılmıştır. Bu form 10 açık uçlu sorudan oluşmaktadır. Bu formun Türkçe uyarlaması Çetinkaya (2017) tarafından yapılmıştır. Türkçe'ye araştırmacı tarafından çevrilen form dil ve anlatım açısından bir dil uzmanına, içerik bilgisi açısından da bir fen eğitimi uzmanına incelettirilmiş ve çeviri form üzerinde bazı küçük değişikliklere gidilmiştir. İngilizce eğitim gören bir grup katılımcıya uygulanan form, üç hafta sonra Türkçe olarak aynı kişilere uygulanmış uyum yüzdeleri incelendikten sonra dilsel eşdeğerlik açısından incelenmesi için tekrar İngilizceye çevrilerek uzmanlara kontrol ettirilmiştir. Uzmanlardan olumlu dönüt alınmasının ardından formun son halinin geçerli ve güvenilir olduğuna karar verilmiştir. Aşağıda formun içerdiği soruların ilişkili olduğu alt boyutlar tablo halinde sunulmuştur.

Tablo 2

VNOS-D+'nin Bilim Doğası Boyutları ile İlişkisi

\begin{tabular}{|c|c|c|c|c|c|c|c|c|c|c|c|}
\hline \multirow[b]{2}{*}{ Bilimin doğası boyutları } & \multicolumn{11}{|c|}{ VNOS-D+'da yer alan sorular } \\
\hline & 1 & 2 & 3 & 4 & & 5 & 6 & 7 & 8 & 9 & 10 \\
\hline & & & & $a-b$ & $\mathrm{c}-\mathrm{d}$ & & & & & & \\
\hline Bilimin değişken doğası & $\mathrm{X}$ & $\mathrm{X}$ & $\mathrm{X}$ & & & & & & & $\mathrm{X}$ & \\
\hline Bilimin ampirik doğası & $\mathrm{X}$ & $\mathrm{X}$ & & & $\mathrm{X}$ & & & & & & \\
\hline Bilimin yaratıcı doğası & $\mathrm{X}$ & $\mathrm{X}$ & & & & & $\mathrm{X}$ & $\mathrm{X}$ & & & \\
\hline Kanun ve teoriler & $\mathrm{X}$ & $\mathrm{X}$ & & & & & & & $\mathrm{X}$ & & \\
\hline Gözlem ve çıkarımlar & $\mathrm{X}$ & $\mathrm{X}$ & & $\mathrm{X}$ & & $\mathrm{X}$ & $\mathrm{X}$ & & & & \\
\hline Bilimin subjektif doğası & $\mathrm{X}$ & $\mathrm{X}$ & & & $\mathrm{X}$ & & & & & & \\
\hline Bilimin sosyal ve kültürel doğası & $\mathrm{X}$ & $\mathrm{X}$ & & & $\mathrm{X}$ & & & & & $\mathrm{X}$ & $\mathrm{X}$ \\
\hline
\end{tabular}

Tablo 2'de görüldüğü üzere form bilimin doğasının yedi boyutuna odaklanmıştır. Buna karşın araştırmada kullanılan etkinlikler bilimsel bilginin ampirik, değişken, subjektif ve yaratıcı doğası ile ilişkilidir. Bu nedenle çalışmada spesifik olarak bilimsel bilginin ampirik doğasına (Madde 1), bilimsel bilginin değişken doğasına (Madde 3), bilimsel bilginin sübjektif doğasına (Madde 4c) ve bilimsel bilginin yaratıcı doğasına (Madde 7) odaklanan sorular araştırma konusu yapılmıştır. Dolayısıyla mevcut araştırmada yalnızca bilimin doğasının bahsi geçen dört boyutunu sorgulayan sorulara 
yönelik analiz gerçekleştirilmiştir. Ayrıca araştırma konusu yapılan boyutlar tablo üzerinde mavi renk ile işaretlenmiştir.

\section{Etkinlikler}

Araştırmada Yalaki (2016) editörlüğünde BİDOMEG projesi kapsamında ortaokul öğrencileri için geliştirilen “Görüyorum!”, “Hayatın Röntgeni” ve "Galen'den Harvey’e Film Gibi” isimli etkinlikler açık-düşündürücü yaklaşımla uygulanmıştır. Aşağıda yer alan Tablo 3'de araştırmada kullanılan etkinlikler ve bu etkinliklerin ilişkili olduğu bilimin doğası boyutları sunulmuştur.

Tablo 3

Etkinliklerin İlişkili Olduğu Bilimin Doğası Boyutları

Bilimin Doğası Boyutları

\begin{tabular}{|c|c|c|c|c|c|c|c|c|}
\hline Etkinlik & 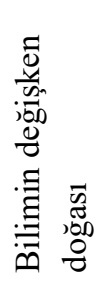 & 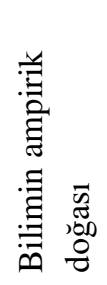 & 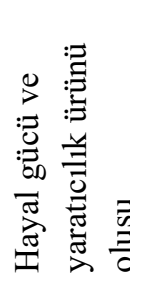 & 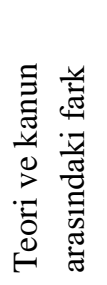 & 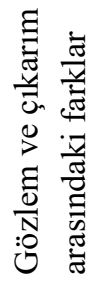 & 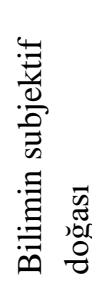 & 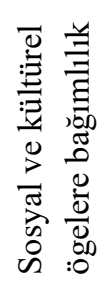 & 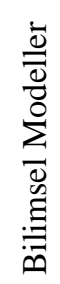 \\
\hline Görüyorum! & $\bullet$ & $\diamond$ & $\diamond$ & & & & & \\
\hline Hayatın Röntgeni & $\diamond$ & $\bullet$ & $\diamond$ & & & $\diamond$ & & \\
\hline Galen'den Harvey'e Film Gibi & $\bullet$ & $\diamond$ & & & & & & \\
\hline Toplam & 3 & 3 & 2 & & & 1 & & \\
\hline
\end{tabular}

Tablo 3’te görüldüğü üzere etkinlikler ağırlıklı olarak bilimsel bilginin değişken, ampirik ve subjektif doğası ile bilimde hayal gücü ve yaratıcılığın rolüne odaklanmaktadır. Araştırmada kullanılan her bir etkinliğe ilişkin açıklamaya aşağıda yer verilmiștir.

Görüyorum!. Öğrencilerin hem hücre kavramının ortaya çıkmasından hücre teorisinin oluşup gelişmesine kadar olan süreci, hem de bilimin doğası temalarını bir arada öğrenmelerinin hedeflendiği bir etkinliktir (Yalaki, 2016). Etkinlik, hücre teorisinin tarihsel gelişiminin drama yoluyla öğretim sürecine dâhil edildiği, öğretmenin anlatıcı rolünü üstlendiği ve bilimsel bilginin doğasına yönelik sınıf içi tartışmaların yapıldığı bir çerçeve çizmektedir. Bu etkinlikte öğrencilerin bilimsel bilginin değişken ve delillere dayalı olduğunu, bilim insanlarının bilimsel bilgi üretirken hayal gücü ve yaratıcılıklarını kullandıklarını anlamaları beklenmektedir.

Hayatın Röntgeni. Bilimde yanılgıların ve subjektif yorumların olabileceğini, bilimsel bilginin üretilmesinde hayal gücü ve yaratıc1lığın rolünün olduğunu öğrencilere kazandırmayı amaçlayan bir etkinliktir (Yalaki, 2016). X ışınlarının keşfinin ardından N ışınlarının keşfedildiği iddiasının işlendiği bu drama etkinliğinde öğrencilerin bilimsel bilginin ampirik doğası, gözlem ve çıkarım arasındaki fark, bilimsel bilginin subjektifliği ile değişken doğasını anlamaları beklenmektedir. 
Galen'den Harvey'e Film Gibi. Bilimin çoğunlukla birikimsel bazen devrimsel bir biçimde ilerlediğini kan dolaşımı üzerinden öğrencilere kazandırmayı amaçlayan (Yalaki, 2016) bu etkinlikte, dolaşım sistemine ilişkin tarihsel bakış açıları yansıtılmıştır. Bu etkinlikle beraber öğrencilerin bilimsel bilginin değişken ve ampirik doğasını anlamaları beklenmektedir.

\section{Uygulama}

Araştırma, 6. sınıf Fen Bilimleri dersinde "Vücudumuzdaki Sistemler" ünitesinde yer alan hücre, destek ve hareket sistemi ve dolaşım sistemi konuları bağlamında tasarlanarak araştırmanın gerçekleştiği tarihte yürürlükte olan Fen Bilimleri Dersi Öğretim Programı'nda ilgili konular için önerilen 24 ders saati boyunca araştırmacı tarafından yürütülmüştür. Araştırma kapsamında öğretimi yapılan konular, bu konulara ait kazanımlar ve ders saati süreleri aşağıda tabloda verilmiştir.

Tablo 4

Etkinliklerin İlişkili Olduğu Konu ve Kazanımlar

\begin{tabular}{|c|c|c|}
\hline Konu & Etkinlik & Kazanım \\
\hline & & $\begin{array}{l}\text { Hayvan ve bitki hücrelerini, temel kısımları ve } \\
\text { görevleri açısından karşılaştırır. }\end{array}$ \\
\hline $\begin{array}{l}\text { Hücre } \\
\text { (6 ders saati) }\end{array}$ & Görüyorum!... & $\begin{array}{l}\text { Geçmişten günümüze, hücrenin yapısı ile ilgili olarak } \\
\text { ileri sürülen görüşleri teknolojik gelişmelerle } \\
\text { ilişkilendirerek tartışır. }\end{array}$ \\
\hline & & Hücre-doku-organ-sistem-organizma ilişkisini açıklar. \\
\hline $\begin{array}{l}\text { Destek ve Hareket } \\
\text { Sistemi } \\
\text { (8 ders saati) }\end{array}$ & Hayatın Röntgeni & $\begin{array}{l}\text { Destek ve hareket sistemine ait yapıları açıklar ve } \\
\text { görevlerini belirterek örnekler verir. } \\
\text { Destek ve hareket sisteminin sağlığını korumak için } \\
\text { yapılması gerekenleri araştırır ve sunar. }\end{array}$ \\
\hline $\begin{array}{l}\text { Dolaşım Sistemi } \\
\text { (10 ders saati) }\end{array}$ & $\begin{array}{l}\text { Galen'den Harvey'e } \\
\text { Film Gibi }\end{array}$ & $\begin{array}{l}\text { Dolaşım sistemini oluşturan yapı ve organları görevleri } \\
\text { ile birlikte açıklar. } \\
\text { Büyük ve küçük kan dolaşımını şema üzerinde } \\
\text { gösterir. } \\
\text { Kanın yapı ve görevlerini kavrar. } \\
\text { Kan grupları arasındaki kan alışverişini kavrar. } \\
\text { Kan bağışının toplum açısından önemini araştırarak } \\
\text { fark eder. } \\
\text { Dolaşım sisteminin sağlığını korumak için yapılması } \\
\text { gerekenleri araştırma verilerine dayalı olarak tartışır. }\end{array}$ \\
\hline
\end{tabular}

Araştırma süreci her iki grupta da Tablo 4'te alıntılanan kazanımlar etrafında yürütülmüştür. Araştırma süresince deney grubu olarak belirlenen Şube I'e açıkdüşündürücü yaklaşımla bilimin doğası öğretimi yapılırken, kontrol grubu olarak belirlenen Şube II'ye ise dolaylı öğretim yaklaşımına uygun olacak biçimde öğretim gerçekleştirilmiştir. 
Deney grubu olarak belirlenen Şube I'de yürütülen dersler fen bilimleri dersi öğretim programının önerdiği kazanımlara ve süreye uygun biçimde yürütülmüştür. Bunun yanında ünitede yer alan konu başlıklarının bitiminde konu alanı ile ilişkili olan bilimin doğası etkinlikleri uygulanmış ve ardından bilimsel bilginin özünde yer alan özellikler tartışma konusu yapılmıştır.

Öğretim programında yer alan Hücre konusuna ilişkin içerik yine program tarafından önerilen öğretim yöntem ve tekniklerine uygun olarak işlendikten sonra "Görüyorum!" etkinliğinde hücre teorisinin ortaya çıkmasında katkısı bulunan beş bilim insanını canlandıracak beş gönüllü öğrenciye görev verilmiştir. Öğrencilere canlandıracakları senaryo önceden verilmiş, öğretmen de anlatıcı rolünü üstlenmiştir. Bu etkinlikte hücre teorisine katkısı olan Hooke, Leeuwenhoek, Schleiden, Schwann ve Virchow isimli bilim insanlarının kronolojik olarak senaryolaştırılmış katkıları öğrenciler tarafından drama etkinliği ile canlandırılmıştır. Etkinlik sırasında öğretmen diğer öğrencilerin de aktif duruma geçmelerini sağlamak için gerekli gördüğü yerlerde bu öğrencilere çeşitli sorular yöneltmiştir. Drama etkinliğinin ardından öğretmen, bilimin doğasının değişken, ampirik ve yaratıcı doğasını kavratmaya yönelik etkinlik metninde önerilen soruları sınıfa yönelterek etkinlik içinde vurgu yapılan bilimsel bilginin değişime açık oluşu, bilim insanlarının yaratıcılıklarını çalışmalarının her aşamalarında kullanabilecekleri ve bilimsel bilginin delillere dayalı olduğunu ilişkin dönütler almaya çalışmıştır. Ardından yine etkinlik metninde önerilen biçimlendirici değerlendirme uygulaması yapılmış ve ilk etkinlik sonlandırılmıştır.

Destek ve Hareket Sistemi konusunda ders içeriği programa uygun yöntem ve tekniklerle işlendikten sonra "Hayatın Röntgeni”" etkinliğine geçilmiştir. Bu etkinlikte bilimde her zaman yanılgılar ve sübjektif yorumlar olabileceğini göstermek, bilim insanlarının araştırmalarında izledikleri yolu anlamak ve bilimsel bilginin gelişiminde yaratıcılığın ve hayal gücünün yerini kavratmak amaçlanmıştır. Bu amaç doğrultusunda X-ışınlarını keşfeden Röntgen, N-1şınlarını keşfettiğini iddia eden Blondlot, bu iddianın doğruluğundan kuşku duyan Nature dergisi editor kurulu ve bu kurulun görevlendirdiği bilim insanı Wood'un bilimsel gelişmelerdeki rollerini vurgulayan bir drama etkinliği yapılacağı öğrencilere bildirilmiştir. Gönüllü olan öğrenciler canlandıracakları bilim insanlarının bilimsel gelişmedeki rollerini ve bu etkinlikte yer alan sahnelerini içeren senaryolara çalışmışlardır. Öğrenciler sınıf ortamında drama etkinliğini sunduktan sonra öğretmen bilim insanlarının özelliklerini, bilimsel araştırmalarda delillerin rollerini, araştırma sürecinde izlenen yolları ve bilimsel araştırmada hayal gücü ve yaratıcılığın yerini tartışmaya açarak bütün öğrencilerin fikirlerini sunmasını sağlamıştır. Ardından biçimlendirmeci değerlendirme aşamasına geçilmiş ve öğrencilerden bilim insanlarının özelliklerini içeren kısa bir paragraf yazmaları istenmiştir. Öğrenci cevapları incelenmiş ve etkinlik kâğıdında önerilen bir alıntı öğretmen tarafından sınıfta okunarak Blondlot'un hikâyesinden çıkarılacak derslere ilişkin fikirler üretilmesi istenmiştir. Son olarak öğretmen Blondlot'un hikâyesinden yola çıkarak bilim insanlarının en nihayetinde insan olduklarını, hırslara ve kıskançlıklara sahip olduklarını, sosyal çevrelerinden ve yaşadıkları ortamın kültüründen etkilendiklerini vurgulamıştır. Yapılan biçimlendirme uygulamalarından sonra etkinlik sonlandırılmıştır.

Dolaşım Sistemi konusunda ise ders içeriği programda belirtilen yöntem ve tekniklerle işlendikten sonra “Galen'den Harvey’e Film Gibi” etkinliğine geçilmiştir. $\mathrm{Bu}$ etkinlikte öğrencilerin kan dolaşım çeşitlerini öğrenmeleri ve bu dolaşım çeşitlerini 
model üzerinde göstermelerinin yanı sıra kan dolaşımının tarihçesini öğrenerek bilimsel bilginin birikimsel ilerlediğini kazandırmak amaçlanmıştır. Bu etkinlikte kan dolaşımı ile ilgili teoriler sunan bilim insanları tanıtılarak özellikle Galen ve Harvey'in teorilerinin özetlendiği bir metin öğrencilere okunmuştur. Ardından etkinlik kâğıtlarında yer alan dolaşım sistemi modelleri öğrencilere gösterilerek hangi bilim insanına ait olduğunun tahmin edilmesi istenmiştir. Öğrencilerin tahminlerinin ardından etkinlik kâğıdında yer alan bilimsel bilginin değişken doğası ile bilimsel bilginin birikimsel yapısına vurgu yapan sorular öğrencilere yöneltilerek bir tartışma ortamı oluşturulmuş ve öğrencilerden dönütler alınmıştır. Yapılan etkinliğin ve öğrencilerin bilimin doğasının ilgili boyutlarında hedeflenen kazanımlara ulaşıp ulaşmadığını kontrol için biçimlendirici değerlendirme yapılarak öğrencilerden bir kalp-damar cerrahı olduklarını düşünmelerini ve kalp-damar şikâyeti ile gelen bir hastanın hastalığını tespit ve tedavi için izleyecekleri yolu açıklamaları istenmiştir. Teşhis ve tedavi süreci ile ilgili fikir sahibi olmayan öğrencilerin çoğunlukta olduğu görüldüğünden anjiyo ve by-pass kavramları açıklanmış ve daha sonra tartışmaya devam edilmiştir. Öğrenci cevapları sınıfça tartışıldıktan sonra etkinliğe son verilmiştir. Şube II'de ise öğretim süreci fen bilimleri dersi öğretim programının önerdiği kazanımlara ve süreye uygun olarak yürütülmüştür. Bu şubede araştırma-sorgulamaya uygun yöntem ve teknikler kullanılan öğretim sürecine ek olarak ders kitabının önerdiği etkinlikler uygulanmıştır. Öğrencilere bilimsel bilginin doğası ile ilgili ayrı bir öğretim gerçekleştirilmemiş, süreç dolaylı yaklaşıma uygun biçimde yürütülmüştür.

\section{Verilerin Analizi}

Araştırmada kullanılan VNOS-D+ formunda doğru veya yanlış cevap bulunmamaktadır. Açık uçlu sorulardan oluşan formda yer alan sorulara öğrencilerin verdiği yanıtlar analiz edilirken iki yol izlenmiştir. İlk aşamada elde edilen veriler içerik analizi ile analiz edilmiştir. Çünkü içerik analizi; belli kurallara dayalı kodlamalarla bir metnin bazı sözcüklerinin daha küçük içerik kategorileri ile özetlendiği sistematik ve yinelenebilir bir taktiktir (Büyüköztürk ve diğerleri, 2009). Öğrencilerin bilimin ampirik, değişken, subjektif ve yaratıcı doğasına yönelik yanıtları kodlanmıştır. Ardından benzer kodlamalar kategoriler altında, cevaplanma sıklığı belirtilerek tablolar halinde sunulmuştur.

İlk aşamadan bağımsız olarak veri analizinin ikinci aşamasında öğrenci görüşlerini ve bu görüşlerdeki değişimi hem bütünsel hem de boyutlar bazında inceleyebilmek için Yalaki ve Çakmakçı (2011) tarafından dilimize uyarlanan dereceli puanlama anahtarı kullanılmıştır. Dereceli puanlama anahtarları, grubun çeşitli boyutlardaki başarı düzeyi hakkında bilgi veren puanlama aracı olarak tanımlanmaktadır (Kutlu, Doğan, \& Karakaya, 2009). Bu araçlar araştırmadan elde edilen nitel verileri sayısallaştırarak istatistiksel analize tutulmasına aracılık ederler. Alanyazın incelendiğinde nitel verilerin sayısallaştırılarak öğrencilerin çeşitli boyutlarda başarılarının incelendiği ve veri aracı olarak hem VNOS-D formunun kullanıldığı (Bala, 2013) hem de farklı ölçme araçlarının kullanıldığ 1 (Çakırlar-Altuntaş, Yılmaz, \& Turan, 2017) çalışmalara rastlamak mümkündür.

Mevcut çalışmada da öğrencilerin formda bulunan sorulara verdikleri yanıtlar araştırmacı ile birlikte fen eğitimi alanında uzman başka bir araştırmacı tarafından "1yetersiz", "2-geçiş aşamasında" ve "3-bilgili" olarak sınıflandırılmıştır. Kodlayıcılar 
arasındaki güvenirliği hesaplamak için Cohen Kappa katsayısı kullanılmıştır. Cohen Kappa katsayısı olarak elde edilen değer 0.61 ile 0.80 arasında ise "iyi düzeyde uyum", 0.81 ile 1.00 arasında ise "çok iyi düzeyde uyum" olduğu kabul edilir (Landis \& Koch, 1977; akt. Kılıç, 2015). Hesaplanan Cohen Kappa katsayısı iki kodlayıcı arasında çok iyi düzeyde uyum olduğunu göstermektedir [k=0.83]. Grupların örneklem sayılarının az olmasından ötürü verilerin normal dağılım gösterip göstermediğini tespit etmek için normallik testi yapılmıştır. Verilerin normal dağılımını incelemek için KolmogorovSmirnov, Shapiro-Wilk, Ki-kare uygunluk testi ve basıklık-çarpıklık değer karşılaştırması kullanılmaktadır (Albayrak, 2009, s. 212). Bu araştırmada KolmogorovSmirnov ve Shapiro-Wilk normallik testine başvurulmuştur. Aşağıda KolmogorovSmirnov (K-S) ve Shapiro-Wilk (S-W) normallik testlerinden elde edilen bulgular tablo olarak verilmiştir.

Tablo 5

Normallik Testi $(K-S)$ ve $(S-W)$ Sonuçlart

\begin{tabular}{rcccccc}
\hline & \multicolumn{3}{c}{ Kolmogorov-Smirnov $^{(\text {a) }}$} & \multicolumn{3}{c}{ Shapiro-Wilk } \\
\hline Otatistic & $d f$ & $p$ & Statistic & $d f$ & $p$ \\
On-test & .187 & 75 & .000 & .873 & 75 & .000 \\
Son-test & .170 & 75 & .000 & .942 & 75 & .002 \\
\hline
\end{tabular}

Büyüköztürk ve diğerleri (2009, s. 42), hesaplanan p değerinin $\alpha=.05$ 'den büyük çıkması verilerin normal dağılım gösterdiğini ifade etmektedir. Tablo 5'te yer alan veriler incelendiğinde hem Kolmogorov-Smirnov, hem de Shapiro-Wilk test sonuçlarının $p<0.05$ olarak hesaplandığı görülmektedir. $\mathrm{Bu}$ durum verilerin normal dağılım göstermediği şeklinde yorumlanabilir.

Normal dağılım göstermeyen verilerin analizinde parametrik olmayan testler tercih edilmektedir. Mann Whitney $U$ testi, iki ilişkisiz örneklemden elde edilen puanların birbirlerinden anlamlı bir şekilde farklılık gösterip göstermediğini test etmektedir (Büyüköztürk ve diğerleri, 2009, s. 155). Bu araştırmada ön-test son-test eşleştirilmiş kontrol gruplu yarı-deneysel desen kullanıldığından Mann Whitney U testi kullanılmış ve analiz sonuçları 0.05 anlamlılık seviyesinde incelenmiştir. Araştırma kapsamında bilimin ampirik doğası boyutu için Madde 1, bilimin değişken doğası boyutu için Madde 3, bilimin sübjektif doğası için Madde 4c ve bilimin yaratıcı doğası için Madde 7'ye ait puanlar istatistiksel analize tabi tutularak yorumlanmıştır.

\section{Bulgular}

$\mathrm{Bu}$ bölümde araştırma sürecinde uygulanan etkinliklerin öğrencilerin bilimin doğası anlayışlarına etkisi incelenmiştir. Ayrıca etkinliklerin ilişkili olduğu her bir bilimin doğası boyutuna yönelik veriler analiz edilerek başlıklar halinde sunulmuştur.

\section{Bilimin Doğası Görüşlerine Yönelik Bulgular}

Öğrencilerin VNOS-D+ formunun tamamından uygulamadan önce ve sonra aldıkları puanlara ilişkin analiz bulguları Tablo 6'da verilmiştir. 
Tablo 6

Bilimin Doğası Görüşleri Anketi - Form D+ Ön Test - Son Test Puanlarına Yönelik Mann Whitney U Testi Bulgularl

\begin{tabular}{ccccccc}
\hline & & $N$ & Sira ortalamas1 & Sira toplamı & $U$ & $p$ \\
\hline Ön-test & Kontrol grubu & 22 & 22.27 & 490.0 & 237.0 & .124 \\
& Deney grubu & 28 & 28.04 & 785.0 & & .179 \\
\hline \multirow{2}{*}{ Son-test } & Kontrol grubu & 22 & 22.48 & 494.5 & 241.5 & \\
& Deney grubu & 28 & 27.88 & 780.5 & & \\
\hline
\end{tabular}

Tablo 6 incelendiğinde kontrol grubu ile deney grubunun ön-test puanları arasında anlamlı bir farklılığın olmadığı bulunmuştur (U=237.0; p>.05). Etkinlik uygulamalarının ardından gerçekleştirilen son-testten elde edilen puanların karşılaştırılması sonucunda kontrol grubu ile deney grubunun bilimin doğasına yönelik görüşleri arasında istatistiksel olarak anlamlı bir farklılığın olmadığı saptanmıştır $(\mathrm{U}=241.5, p>.05)$. Sira ortalamaları incelendiğinde, hem uygulamadan önce hem de uygulamadan sonra deney grubunda yer alan öğrencilerin puan ortalamalarının kontrol grubunda bulunan öğrencilere kıyasla daha yüksek olduğu görülmektedir.

\section{Bilimin Ampirik Doğasına Yönelik Bulgular}

Öğrencilerin bilimin ampirik doğasına ilişkin görüşleri VNOS-D+ formunda yer alan "Bilim nedir? Bilimi diğer disiplinlerden farklı kılan nedir?" maddeleri ile sorgulanmıştır. Bilimin ampirik doğasına ilişkin bulgular tablolar halinde sunulmuştur.

Tablo 7 incelendiğinde uygulamadan önce kontrol grubunda yer alan öğrencilerin çoğunluğunun ( $n=11)$ bilimi teknoloji ile eşdeğer tuttuğu, az sayida $(n=3)$ öğrencinin bilimi araştırmalar bütünü olarak gördüğü, aynı sayıda $(n=3)$ öğrencinin bilimi bir bilgi türü olarak düşündüğü görülmüştür. Kontrol grubunda sadece bir öğrenci bilimi zekâ olarak düşünürken, bir öğrenci de bilimi doğal dünyanın işleyişine yönelik girişimler olarak tanımlamıştır. Ayrıca üç öğrenci bilimin ne olduğuna dair fikir beyan etmemiştir. Uygulamadan sonra kontrol grubunda bilimin teknoloji olduğunu düşünen öğrenci sayısında $(n=7)$ azalma meydana gelirken, bilimi araştırma olarak ifade eden öğrenci sayısında $(n=5)$ ise artış olduğu görülmüştür. Bunun yanında bilimin bir bilgi biçimi olduğunu dile getiren öğrenci sayısında da $(n=6)$ artış meydana gelmiştir. Uygulamanın ardından öğrencilerden biri bilimi okuldaki derslerle özdeşleştirerek tanımlarken, başka bir öğrenci bilimin bir konu alanı, bir dal olduğunu ifade etmiştir. Ayrıca uygulamadan sonra da bilimin ne olduğuna ilişkin açıklama yapmayan bir öğrenci olduğu görülmüştür. 
Tablo 7

Bilimin Ampirik Doğasına Yönelik Bulgular

\begin{tabular}{|c|c|c|c|c|}
\hline & \multicolumn{2}{|c|}{ Kontrol Grubu } & \multicolumn{2}{|c|}{ Deney Grubu } \\
\hline & $\begin{array}{l}\text { Uygulama } \\
\text { öncesi }\end{array}$ & $\begin{array}{l}\text { Uygulama } \\
\text { sonrasi }\end{array}$ & $\begin{array}{l}\text { Uygulama } \\
\text { öncesi }\end{array}$ & $\begin{array}{l}\text { Uygulama } \\
\text { sonras1 }\end{array}$ \\
\hline & $\mathrm{n}$ & $\mathrm{n}$ & $\mathrm{n}$ & $\mathrm{n}$ \\
\hline Teknoloji & 11 & 7 & 7 & 5 \\
\hline Araştırma & 3 & 5 & 9 & 9 \\
\hline Bilgi & 3 & 6 & 3 & 6 \\
\hline Kanıtlanmış bilgi & - & - & - & 2 \\
\hline Zekâ & 1 & - & - & - \\
\hline $\begin{array}{l}\text { Doğanın işleyişi / Olguların } \\
\text { incelenmesi }\end{array}$ & 1 & - & 2 & - \\
\hline Ders / Disiplin & - & 2 & - & - \\
\hline Bilinmeyeni anlama çabası & - & 1 & 1 & - \\
\hline Söylenti & - & - & 1 & 1 \\
\hline Bilim insanlarının ürettikleri & - & - & - & 2 \\
\hline Fikri yok & 3 & 1 & 5 & 3 \\
\hline Toplam & 22 & 22 & 28 & 28 \\
\hline
\end{tabular}

Deney grubunda yer alan öğrencilerin uygulamadan önce verdikleri yanıtlar analiz edildiğinde, öğrencilerin önemli bir bölümünün $(n=9)$ bilimi araştırma olarak düşündükleri, yine azımsanmayacak sayıda öğrencinin $(n=7)$ bilimin teknoloji ile aynı anlama geldiğini düşündükleri görülmüştür. Bu grupta üç öğrenci bilimi bir bilgi türü olarak tanımlarken, iki öğrenci bilimi doğal olguları inceleyen bir disiplin olarak ifade etmiştir. Ayrıca bir öğrenci bilimi bilinmeyeni anlama, gerçeği açığa çıkarma girişimi şeklinde düşünürken, bir öğrenci de bilimi bir söylenti ile eşdeğer tutmuştur. Deney grubunda beş öğrencinin bilimin tanımı ile ilgili fikri olmadığı belirlenmiştir. Uygulamadan sonra ise bilimi araştırma olarak gören öğrenci sayısında $(n=7)$ bir değişiklik meydana gelmezken, bilimi teknoloji ile eşdeğer tutan öğrencilerin bir miktar azaldığı $(n=5)$ görülmüştür. Bilimi bilgi biçimi olarak gören öğrenci sayısı $(n=6)$ önemli bir artış gösterirken, iki öğrenci bilimi kanıtlanmış bilgiler topluluğu olarak ifade etmiştir. Bilimin söylenti olduğunu düşünen öğrenci bu görüşünü korurken, uygulamadan önce bahsedilmeyen yeni bir tanımlamaya da rastlanmıştır. Buna göre iki öğrenci bilimi, bilim insanlarının ürettikleri şeyler şeklinde tanımlamıştır. Uygulamadan sonra bilimin tanımına ilişkin açıklama yapmayan öğrenci sayısının $(n=3)$ da azaldığı belirlenmiştir. Araştırmadan elde edilen bütün bu bulgular öğrencilerin bilimin ampirik doğasına yönelik çeşitli yanılgılara sahip olduğunu göstermektedir. Aşağıda uygulama öncesi ve sonrasında bilimin ampirik doğasına yönelik kontrol ve deney grubunda yer alan öğrenci görüşlerinden alıntılara yer verilmiştir.

“Insanların icat ettiği herhangi bir şeye bilim denir. K. Grubu Ö12 (uyg. öncesi).”

"Bilim hayvanlarl, insanları, bitkileri, mikroskobik canlıları incelemeye ve onlar hakkında yeni şeyler keşfetmeye denir. D. Grubu Ö26 (uyg. öncesi). ” 
“Bir şeyin üzerinde deney ve araştırmaya bilim denir. K. Grubu Ö13 (uyg. sonrası).”

"Deneyler ve gözlem yaparak elde edilen bilginin doğrulandı̆̆ı bir dal. D. Grubu Ö6 (uyg. sonrasi)."

$K=$ Kontrol,$\quad D=$ Deney, $\ddot{O}=\ddot{O} \breve{g r e n c i}$, uyg. $=$ Uygulama

Yukarıda verilen ilk alıntıda, öğrencinin bilimi teknolojik bir girişim olarak düşündüğü görülmektedir. İkinci alıntıda ise gözlem içeren bir araştırma süreci sonucunda ortaya konulan yeni bilgilerin bilim olduğunu ifade eden bir öğrenci yanıtı görülmektedir. Üçüncü alıntıda öğrencinin deney ile araştırmayı birbirinden ayırdığı ve bilimin herhangi bir konuda ikisini içeren bir disiplin olduğunu ifade ettiği görülmüştür. Son alıntıda ise bilimin deney ve gözlem içerdiğini ifade eden öğrenci, bilimin doğrulanmaya dayalı olduğunu ifade ederek pozitivist bir anlayışa sahip olduğunu göstermiştir.

Öğrencilerin Bilimin Doğası Görüşleri Anketi - From D+'ta yer alan bilimin ampirik doğasına yönelik soruya verdikleri cevapların dereceli puanlama anahtarı ile kodlanmasından elde edilen veriler analiz edilmiş ve analiz bulguları aşağıda Tablo 6' da sunulmuştur.

Tablo 8

Bilimin Ampirik Doğasına Yönelik Mann Whitney U Testi Bulguları

\begin{tabular}{ccccccc}
\hline & $N$ & Sira ortalamas1 & Sira toplamı & $U$ & $p$ \\
\hline \multirow{2}{*}{ Ön-test } & Kontrol grubu & 22 & 24.00 & 528.0 & 275.0 & .117 \\
& Deney grubu & 28 & 26.88 & 747.0 & & \\
\hline \multirow{2}{*}{ Son-test } & Kontrol grubu & 22 & 24.95 & 549.0 & 296.0 & .713 \\
& Deney grubu & 28 & 25.93 & 726.0 & \\
\hline
\end{tabular}

Tablo 8'de uygulamadan önce kontrol grubu ile deney grubunun bilimin ampirik doğasına ilişkin görüşleri arasında anlamlı bir farklılık olmadığı görülmektedir $(\mathrm{U}=275.0 ; p>.05)$. Uygulamadan sonra da kontrol grubu ile deney grubunun bilimin ampirik doğasına ilişkin görüşlerinde anlamlı bir fark meydana gelmemiştir ( $U=296.0$; $p>.05)$. Grupların sıra ortalamaları incelendiğinde hem ön-testte hem de son-testte deney grubunda yer alan öğrencilerin ilgili maddeden daha yüksek puan aldıkları görülmektedir. Buna karşın son-testte deney grubunda bulunan öğrencilerin aldığ puanlarda azalmalar olurken, kontrol grubunda yer alan öğrencilerin aldığı puanlarda artışlar meydana gelmiştir.

\section{Bilimin Değişken Doğasına Yönelik Bulgular}

Öğrencilerin bilimin değişken doğasına ilişkin görüşleri VNOS-D+ formunda yer alan "Bilim insanları bilimsel bilgi üretirler. Sizce bilimsel bilgi gelecekte değişebilir mi?" ifadesi ile sorgulanmıştır. Analiz sonucunda elde edilen bulgulara Tablo 9'da yer verilmiştir. 
Tablo 9

Bilimin Değişken Doğasına Yönelik Bulgular

\begin{tabular}{|c|c|c|c|c|c|}
\hline & & \multicolumn{2}{|c|}{ Kontrol Grubu } & \multicolumn{2}{|c|}{ Deney Grubu } \\
\hline & & $\begin{array}{l}\text { Uygulama } \\
\text { öncesi }\end{array}$ & $\begin{array}{l}\text { Uygulama } \\
\text { sonras1 }\end{array}$ & $\begin{array}{l}\text { Uygulama } \\
\text { öncesi }\end{array}$ & $\begin{array}{l}\text { Uygulama } \\
\text { sonrası }\end{array}$ \\
\hline & & $n$ & $n$ & $n$ & $n$ \\
\hline \multirow{4}{*}{$\begin{array}{l}\text { Bilimsel bilgi } \\
\text { değişir }\end{array}$} & Teknolojideki değişim & 9 & 12 & 9 & 3 \\
\hline & Bilgideki değişim & 1 & 6 & 5 & 15 \\
\hline & Günlük yaşamdaki değişim & 1 & - & - & 1 \\
\hline & Açıklama yok & 3 & 3 & 3 & 6 \\
\hline & Toplam & 14 & 21 & 17 & 25 \\
\hline \multirow[t]{4}{*}{$\begin{array}{l}\text { Bilimsel bilgi } \\
\text { değişmez }\end{array}$} & $\begin{array}{l}\text { Bilimsel bilginin kesin } \\
\text { olmas1 }\end{array}$ & 1 & 1 & 2 & - \\
\hline & Örnek yokluğu & 1 & - & - & - \\
\hline & Açıklama yok & 1 & - & 6 & 2 \\
\hline & Toplam & 3 & 1 & 8 & 2 \\
\hline Fikri yok & & 5 & - & 3 & 1 \\
\hline
\end{tabular}

Tablo 9'da görüldügü üzere, uygulamadan önce kontrol grubundaki öğrencilerin, önemli bir bölümü $(n=14)$ bilimsel bilginin değişebileceğini ifade ederken, üç öğrenci bilimsel bilginin değişmeyeceğini, beş öğrenci ise bilimsel bilginin değişkenliğine yönelik fikri olmadığını dile getirmiştir. Uygulamadan sonra kontrol grubunda bulunan öğrencilerin çok büyük kısmının $(n=21)$ bilimsel bilginin değişebileceği yönünde yanıtlar paylaştığı belirlenmiştir. Uygulamanın ardından kontrol grubunda bilimsel bilginin değişmeyeceğini ifade eden sadece bir öğrenci kalırken, değişkenliğe yönelik fikri olmayan öğrenciye rastlanmamıştır. Benzer biçimde uygulamadan önce deney grubunda yer alan öğrencilerin büyük kısmı $(n=17)$ bilimsel bilginin değişebileceğini, öğrencilerin bir kısmı $(n=8)$ ise bilimsel bilgide değişim olmayacağını ifade ederken, iki öğrencinin ise değişkenliğe yönelik fikrinin olmadığı saptanmıştır. Uygulamanın ardından deney grubundaki öğrencilerin büyük kısmının $(n=25)$ bilimsel bilginin değişebileceğini düşündüğü, iki öğrencinin bilimsel bilgide değişim meydana gelmeyeceğini ifade ettiği, yalnızca bir öğrencinin bilimsel bilginin değişkenliğine yönelik fikir sahibi olmadığı saptanmıştır.

Bilimin değişken doğasına yönelik öğrenci yanıtları incelendiğinde, uygulama öncesinde hem kontrol grubunda hem de deney grubunda yer alan öğrencilerin önemli kısmının ( $n=9)$ bilimsel bilgideki değişimi teknolojideki değişim ve gelişim olarak düşündükleri görülmüştür. Uygulamanın ardından kontrol grubunda bu şekilde düşünen öğrenci sayısının arttığı $(n=12)$, deney grubundaki öğrenci sayısının ise önemli oranda $(n=3)$ azaldığı saptanmıştır. Uygulamadan önce kontrol grubunda bilimin değişken doğasını, bilgideki değişim olarak yorumlayan öğrenci sayısı yalnızca bir iken, uygulamadan sonra bu sayının altıya yükseldiği belirlenmiştir. Deney grubunda ise uygulamadan önce beş öğrencinin bilimsel bilgideki değişimi bilgide meydana gelen değişim olarak düşündüğü, uygulamadan sonra bu sayının önemli ölçüde $(n=15)$ artış 
gösterdiği görülmüştür. Ayrıca uygulamadan önce her iki gruptan üç öğrencinin bilimsel bilginin değişken olduğunu ifade etmesine karşın bu duruma bir açıklama getirmediği, uygulamadan sonra açıklama sunmayan öğrenci sayısının kontrol grubunda değişmediği ancak deney grubunda altıya yükseldiği saptanmıştır. Araştırma bulguları öğrencilerin bilimin değişken doğasına yönelik bazı yanılgıları olduğunu göstermektedir. Özellikle bilimdeki değişimi teknolojik değişim olarak görmenin yaygın bir inanış olduğu görülmüştür. Buna karşın uygulanan etkinliklerin bu inanışı azaltmada etkili olduğu da dikkat çekmektedir. Aşağıda bilimsel bilgideki değişimi ifade eden öğrenci yanıtlarından alıntılar sunulmuştur.

"Bilimsel bilgi değişsebilir. Mesela bilgisayarn ilk hali ile son hali bir değildir. K. Grubu Ö5 (uyg. öncesi)."

"Bilimsel bilgi gelecekte değișebilir. Bir bilgi öğrenilir, başka bilginin yanlış olduğu ortaya çıkar ve yanlış bilgi değişir. D. Grubu Ö23 (uyg. öncesi)."

"Değişebilir. Çünkü yeni bilgiler üretildikçe her bilgi değişebilir. Bir hücreye ilkel mikroskoplar ile bakıldı̆̆ında içi boş odacıklar olduğu söylenmiş ama daha sonra mikroskoplar gelişstikçe hücrenin içi boş olmadığı anlaşılmış ve ilk bilgi değişmişs. K. Grubu Ö14 (uyg. sonrasl)."

"Evet değiş̧ebilir. Mesela Galen bir teori sunmuş. O zamanlar başka teori olmadığı için o kabul edilmiş. Yıllar sonra Harvey bir teori sunmuş, delil de göstermiş, o yüzden değişebilir. D. Grubu Ö28 (uyg. sonrast)."

$K=$ Kontrol, $\quad D=$ Deney, $\ddot{O}=\ddot{O} g$ renci, uyg. $=$ Uygulama

Uygulama öncesi yanıtlardan alıntılar incelendiğinde bilimsel bilginin değişebileceğini ifade eden ilk öğrencinin bilimi teknoloji ile eşdeğer gördüğü ve bilimsel bilgide meydana gelen değişimin teknolojideki değişim olduğunu ifade ettiği görülmektedir. İkinci öğrenci ise yeni bilgiler ışığında eski bilgilerin terk edilebileceğini ve bilimsel bilginin değişime uğrayabileceğini düşünmektedir. Uygulamadan sonra öğrencilerin etkinliklerde yer alan bilim tarihi örneklerine atıfta bulunarak bilimsel bilginin teknolojik gelişmeler ile yeni deliller 1şı̆̆ında uzun yıllar sonunda da olsa değişebileceğini ifade ettikleri görülmüştür.

Bilimsel bilginin değişmediğini düşünen az sayıda öğrenci gerekçe olarak sahip oldukları bilimsel bilgilerin değişmemiş olmasını ya da bilimsel bilginin kesin olmasını örnek göstermiştir. Bilimsel bilginin değişmediğini ifade eden öğrenci yanıtları aşağıda alıntılanmıştır.

"Değişmez. Doğru bilgi doğru olarak, yanlış bilgi de yanlış olarak kalır. Örneğin dünyanın yuvarlak olduğunu bilen herkes bunun doğru olduğunu söyler. Bu bilgi bu zamana kadar değiş̧mediyse gelecekte de değişmez. K. Grubu Ö17 (uyg. öncesi)."

"Bilimsel bilgi zaten kesin olana kadar açıklanmaz. Kesin olduktan sonra da değişmez. D. Grubu Ö8 (uyg. sonrast)."

$K=$ Kontrol,$\quad D=$ Deney, $\ddot{O}=\ddot{O} \breve{g r e n c i}$, uyg. $=$ Uygulama

Bilimsel bilginin değişmediğini ifade eden ilk öğrencinin değişmiş bilimsel teori örneği bilmediği, bu nedenle bilimsel bilginin değişemeyeceğini düşündüğü ve bu düşüncesini zamana genellediği görülmektedir. Bununla beraber ikinci öğrencinin bilimin kesin olduğunu düşündüğü ve kesin bilgilerin değişmeyeceğini ifade ettiği belirlenmiştir.

Öğrencilerin Bilimin Doğası Görüşleri Anketi - From D+'ta yer alan bilimin değişken doğasına yönelik soruya verdikleri cevapların dereceli puanlama anahtarı ile 
kodlanmasından elde edilen veriler analiz edilmiş ve analiz bulguları aşağıda Tablo 10'da sunulmuştur.

Tablo 10

Bilimin Değişken Doğasına Yönelik Mann Whitney U Testi Bulguları

\begin{tabular}{ccccccc}
\hline & & Sira ortalaması & Sira toplamı & $U$ & $p$ \\
\hline Ön-test & Kontrol grubu & 22 & 23.91 & 526.0 & 273.0 & .324 \\
& Deney grubu & 28 & 26.75 & 749.0 & & \\
\hline \multirow{2}{*}{ Son-test } & Kontrol grubu & 22 & 21.23 & 467.0 & 214.0 & .032 \\
& Deney grubu & 28 & 28.86 & 808.0 & & \\
\hline
\end{tabular}

Tablo 10'da bilimin değişken doğasına yönelik öğrenci görüşlerinin sorgulandığ1 maddeden kontrol grubu ile deney grubunun uygulamadan önce aldıkları puanlar arasında anlamlı bir fark olmadığı görülmektedir $(\mathrm{U}=273.0 ; p>.05)$. Buna karşın grupların son-test puan karşılaştırmalarında ise deney grubu lehine anlamlı bir farklılığın ortaya çıktığı dikkat çekmektedir $(\mathrm{U}=214.0 ; p<.05)$. Ayrıca grupların sıra ortalamaları, deney grubunda yer alan öğrencilerin kontrol grubunda yer alan öğrencilere kıyasla bilimin değişken doğasının sorgulandığı maddeden daha yüksek puanlar aldığını göstermektedir.

\section{Bilimin Subjektif Doğası}

Bilimin subjektif doğasına ilişkin öğrenci görüşleri VNOS-D+ formunda yer alan "Bilim insanları dinozorları neslinin 65 milyon yıl önce tükendiği (hepsinin yok olduğu) konusunda uzlaşı halindedir. Ancak, bilim insanları dinozorların neslinin nasıl tükendiği konusunda farklı fikirlere sahiptirler. Sizce bilim insanları aynı bilgiye sahip olmalarına rağmen neden bu konuda farklı düşünmektedirler?" maddesi ile sorgulanmıştır. Bilimin subjektif doğasına ilişkin bulgular Tablo 11'de sunulmuştur.

Tablo 11'de uygulamadan önce kontrol grubunda önemli sayıda $(n=10)$ öğrencinin sorgulanan duruma ilişkin bir fikrinin olmadığ görülmektedir. Öğrencilerin bir kısmı $(n=4)$ aynı verilere dayalı araştırmalarda farklı sonuçlara ulaşılmasını bilim insanlarının düşünme biçimlerinin farklı olmasına, bir kısmı $(n=3)$ araştırmaya başlarken farklı ön bilgilere sahip olmalarına dayandırmışlardır. Bununla beraber kontrol grubundan iki öğrenci araştırmalarda yetersiz ön bilgilere sahip olunmasının araştırmacıları farklı sonuçlara götürdüğünü ifade ederken, bir öğrenci bu farklılığın bilim insanlarının kişisel özelliklerinin farklı olmasından kaynaklandığını belirtmiştir. Ayrıca bir öğrenci araştırmacıların hatalı sonuçlara ulaşmasının da farklılıklara yol açabileceğini dile getirirken, başka bir öğrenci ise geçmişte gerçekleşen ve kesin cevabı olmayan olgulara birden fazla durumun yol açabileceğini ifade etmiştir. Uygulamadan sonra kontrol grubunda fikir beyan etmeyen öğrenci sayısında $(n=11)$ artış görülürken, araştırmalarda farklı sonuçlara ulaşmaya gerekçe olarak hatalı araştırma yapılması, kişisel özelliklerin farklı olması ve olası nedenlerin farklı olması cevaplarına rastlanmamıştır. Öğrenciler bilim insanlarının farklı düşünmelerinin $(n=6)$, farklı ön bilgilerle araştırmalara başlamalarının $(n=2)$ ve yetersiz ön bilgilere sahip olmalarının $(n=2)$ farklı araştırma sonuçlarına yol açacağını dile getirmişlerdir. 
Tablo 11

Bilimin Subjektif Doğasına Yönelik Bulgular

\begin{tabular}{|c|c|c|c|c|}
\hline & \multicolumn{2}{|c|}{ Kontrol Grubu } & \multicolumn{2}{|c|}{ Deney Grubu } \\
\hline & $\begin{array}{l}\text { Uygulama } \\
\text { öncesi }\end{array}$ & $\begin{array}{l}\text { Uygulama } \\
\text { sonras1 }\end{array}$ & $\begin{array}{l}\text { Uygulama } \\
\text { öncesi }\end{array}$ & $\begin{array}{l}\text { Uygulama } \\
\text { sonras1 }\end{array}$ \\
\hline & $n$ & $n$ & $n$ & $n$ \\
\hline Farklı düşünme & 4 & 6 & 8 & 6 \\
\hline Farklı ön bilgiye sahip olma & 3 & 2 & 2 & 1 \\
\hline Yetersiz ön bilgiye sahip olma & 2 & 2 & 4 & 6 \\
\hline Farklı hayal gücüne sahip olma & - & - & - & 2 \\
\hline $\begin{array}{l}\text { Farklı kişisel özelliklere sahip } \\
\text { olma }\end{array}$ & 1 & - & - & - \\
\hline Farklı yorumlama & - & 1 & 1 & - \\
\hline Hatalı araştırma & 1 & - & - & - \\
\hline Olası nedenlerin fazlalığı & 1 & - & 3 & - \\
\hline Marjinallik & - & - & 1 & 1 \\
\hline Fikri yok & 10 & 11 & 9 & 12 \\
\hline Toplam & 22 & 22 & 28 & 28 \\
\hline
\end{tabular}

Deney grubunda da benzer şekilde öğrencilerin önemli kısmının $(n=9)$ uygulamadan önce bilimin subjektif doğasına yönelik fikri olmadığı, bu sayının uygulamadan sonra artış gösterdiği $(n=12)$ görülmektedir. Uygulamadan önce öğrencilerin bir bölümü $(n=8)$ farklı araştırma sonuçlarına bilim insanlarının farklı düşünmelerinin, bir bölümü $(n=4)$ yetersiz ön bilgiye sahip olmalarının, bir bölümü de olası nedenlerin fazlalığının sebep olduğunu dile getirmişlerdir. Ayrıca bilim insanlarının farklı ön bilgilere sahip olduğunu $(n=2)$, verileri farklı yorumladıklarını $(n=1)$ ve aykırı görünme çabası içerisinde olduklarını $(n=1)$ ifade eden öğrencilere de rastlanmıştır. Uygulamadan sonrasında deney grubunda önemli sayıda öğrenci $(n=6)$ farklı sonuçlara kaynaklık eden durumların bilim insanlarının farklı düşünmeleri ve yetersiz ön bilgilerden kaynaklandığını belirtmiştir. Bununla beraber bazı öğrenciler bilim insanlarının farklı hayal güçlerine sahip olmalarının $(n=2)$, farklı ön bilgilere sahip olmalarının $(n=1)$ ve marjinal görünme çabalarının $(n=1)$ değişik sonuçlar elde etmelerine neden olduğunu düşünmektedirler. Öğrenciler, bilim insanlarının araştırmalarında farklı sonuçlara ulaşmalarını çeşitli şekillerde açıklamışlardır. Araştırma bulguları öğrencilerin, bilim insanlarının kişisel özelliklerinin, düşünce yapılarının ve yorumlama kabiliyetlerinin araştırmalarını etkilediği düşüncesine sahip olduğunu göstermektedir. Bu durum öğrencilerin bu boyuta ilişkin yeterli düzeyde bir anlayışa sahip olduklarını ortaya koymaktadır. Aşağıda bilimin subjektif doğasını örnekleyen alıntılara yer verilmiştir.

"Hepsi farklı bir akla sahipler. Bu nedenle hepsi farklı düşünüyor. K. Grubu Ö2 (uyg. öncesi)."

“Çünkü ortada net bir cevap olmadı̆̆ını düşünüyorum. Bilim insanları da farklı teorileri olmasına ră̆men en yakın cevabı kabullenmişlerdir. D. Grubu Ö22 (uyg. öncesi).” 
"Hepsi dinozorlara farkll tarafindan bakıyorlar. K. Grubu Ö10 (uyg. sonrasl)."

"Çünkü nesillerinin nasıl tükendiği hakkında hiçbir bilgi yoktur. Bilim insanları da kendi teorilerini öne sürüyorlar. D. Grubu Ö28 (uyg. sonrası)."

$K=$ Kontrol,$\quad D=$ Deney,$\ddot{O}=\ddot{O} \breve{g r e n c i}$, uyg. $=$ Uygulama

Alıntılar incelendiğinde öğrenciler, bilim insanlarının aynı verilere sahip olmalarına rağmen farklı sonuçlara ulaşmalarına; farklı düşünmelerinin, kesin bir cevap olmamasının, verileri farklı yorumlamalarının ve yetersiz ön bilgiye sahip olmalarının yol açtığııı ifade etmişlerdir.

Öğrencilerin Bilimin Doğası Görüşleri Anketi - From D+'ta yer alan bilimin subjektif doğasına yönelik soruya verdikleri cevapların analizinden elde edilen bulgular aşağıda Tablo 12 'de sunulmuştur.

Tablo 12

Bilimin Subjektif Doğasına Yönelik Mann Whitney U Testi Bulguları

\begin{tabular}{ccccccc}
\hline & & & Sira ortalamas1 & Sira toplamı & $U$ & $p$ \\
\hline \multirow{2}{*}{ Ön-test } & Kontrol grubu & 22 & 24.07 & 529.5 & 276.5 & .375 \\
& Deney grubu & 28 & 26.63 & 745.5 & & \\
\hline \multirow{2}{*}{ Son-test } & Kontrol grubu & 22 & 24.05 & 529.0 & 276.0 & .401 \\
& Deney grubu & 28 & 26.64 & 746.0 & & \\
\hline
\end{tabular}

Tablo 12'de sıra ortalamaları incelendiğinde ön-testte kontrol grubu ile deney grubunu öğrencilerinin aldıkları puan ortalamalarında deney grubu lehine bir farklılık olduğu saptanmıştır. Uygulama öncesinde grupların aldıkları puanlara ilişkin analiz sonuçları incelendiğinde iki grup arasında bilimin subjektif doğası boyutunda anlamlı bir fark olmadığı görülmektedir $(\mathrm{U}=276.5 ; p>.05)$. Etkinliklerin uygulanmasının ardından grupların sıra ortalamaları incelendiğinde, ihmal edilecek kadar az bir değişimin gerçekleştiği tespit edilmiştir. Bu tespite uygun biçimde bu boyutta kontrol ve deney gruplarının son-test puanları arasında anlamlı bir fark olmadığı belirlenmiştir $(\mathrm{U}=276.0 ; p>.05)$.

\section{Bilimin Yaratıcı Doğasına Yönelik Bulgular}

Bilimin yaratıcı doğasına ilişkin öğrenci görüşleri VNOS-D+ formunda yer alan "Bilim insanları problemlerine cevap bulmak için araştırmalar/deneyler yaparlar. Sizce bilim insanları araştırma/deney yaparken yaratıcılıklarını ve hayal güçlerini kullanırlar mı?" maddesi ile sorgulanmıştır. Öğrenci yanıtlarına ilişkin bulgular aşağıda tablo halinde sunulmuştur.

Tablo 13'te görüldüğü üzere hem kontrol grubunun hem de deney grubunun çok büyük kısmı uygulamanın hem öncesinde hem de sonrasında bilimsel araştırmalarda yaratıcılık ve hayal gücü kullanıldığını ifade etmişlerdir. Her iki grupta da bilimde hayal gücü ve yaratıcılığın olduğunu ifade eden öğrenci sayısında uygulamadan sonra herhangi bir değişim görülmemiştir. Buna karşın kontrol grubunda bilimsel araştırmalarda yaratıcılık ve hayal gücünün rolüne ilişkin uygulamadan önce fikri olmayan öğrencilerin $(n=2)$, uygulamadan sonra bilimde yaratıc1lı ve hayal gücü bulunmadığını düşündüğü belirlenmiştir. Deney grubunda ise uygulamadan önce 
bilimsel araştırmalarda yaratıcılık ve hayal gücü kullanılmadığını ifade eden öğrencilerin sayısında ( $n=4)$ uygulamadan sonra azalma görüldüğü $(n=1)$ ancak diğer öğrencilerin $(n=3)$ herhangi bir fikir sunmadığı tespit edilmiştir. Elde edilen bulgular, öğrencilerin bu boyuta ilişkin yeterli anlayışa sahip olduğunu ortaya koymaktadır. Bununla beraber öğrencilerin yanıtları alıntılanarak aşağıda sunulmuştur.

Tablo 13

Bilimin Yaratıcı Doğasına Yönelik Bulgular

\begin{tabular}{ccccc}
\hline & \multicolumn{2}{c}{ Kontrol Grubu } & \multicolumn{2}{c}{ Deney Grubu } \\
\cline { 2 - 5 } & $\begin{array}{c}\text { Uygulama } \\
\text { öncesi }\end{array}$ & $\begin{array}{c}\text { Uygulama } \\
\text { sonrası }\end{array}$ & $\begin{array}{c}\text { Uygulama } \\
\text { öncesi }\end{array}$ & $\begin{array}{c}\text { Uygulama } \\
\text { sonrası }\end{array}$ \\
\cline { 2 - 5 } & $\mathrm{n}$ & $\mathrm{n}$ & $\mathrm{n}$ & $\mathrm{n}$ \\
\hline Yaratıcılık ve hayal gücü kullanılır & 20 & 20 & 24 & 24 \\
Yaratıcılık ve hayal gücü kullanılmaz & - & 2 & 4 & 1 \\
Fikri yok & 2 & - & - & 3 \\
\hline Toplam & 22 & 22 & 28 & 28
\end{tabular}

"Kullanırlar. Araştırmaların neredeyse her aşamasında hayal gücü ve yaratıcılıklarını kullanırlar. K. Grubu Ö7 (uyg. öncesi)."

"Kullanmiyorlar. Çünkü problemlerini çözerken akıl ve zekâlarını kullanıyorlar. D. Grubu Ö21 (uyg. öncesi)."

"Bence kullaniyorlar. Çünkü hayal etmek de bilime dâhil. Mesela ögretmenler proje görevi verdiklerinde ben hayal ederim bunu böyle yapsam daha güzel olur diye. Bilim insanlar da araştırmalarını yaparken bunun gibi düşünüyorlardır. K. Grubu Ö11 (uyg. sonrasl).”

"Hayır. Orada bir sürü makine var. Niye hayal güçlerini kullansinlar ki? D. Grubu Ö9 (uyg. sonrast)."

$K=$ Kontrol,$\quad D=$ Deney,$\ddot{O}=\ddot{O} \ddot{g r e n c i}$, uyg. $=$ Uygulama

Yukarıdaki alıntılarda bilim insanlarının hayal güçlerini kullandıklarını düşünen öğrencilerin bu iddialarını gerekçeler sunarak açıkladıkları ve araştırmalarının hangi aşamalarında yaratıcılıklarını kullandıklarına dair fikir sundukları görülmektedir. Ayrıca bilimde hayal gücü ve yaratıcılığın yeri olmadığını düşünen öğrenciler hayal gücü ve yaratıcılığa gerek olmamasını zekâ ve teknolojinin varlığını gerekçe göstererek açıklamışlardır.

Öğrencilerin bilimin yaratıcı doğasına yönelik soruya verdikleri yanıtlardaki değişim istatistiksel olarak analiz edilmiş ve bulgular aşağıda tablo halinde sunulmuştur. Tablo 14'te grupların sira ortalamaları incelendiğinde kontrol grubu ile deney grubunun ön-testte aldıkları puanların birbirine yakın olduğu görülmektedir. Uygulamadan önce kontrol grubu ile deney grubunun bilimin yaratıcı doğasına yönelik görüşleri arasında istatistiksel olarak anlamlı bir farklılık bulunamamıştır $(\mathrm{U}=306.5 ; p>.05)$. Grupların sıra ortalamaları incelendiğinde, son-testte deney grubu lehine bir artış olduğu dikkat çekmektedir. Buna rağmen etkinliklerin uygulanmasının ardından grupların ilgili boyuttan aldıkları puanlar arasında anlamlı bir değişiklik meydana gelmemiştir $(\mathrm{U}=275.0 ; p>.05)$. 
Tablo 14

Bilimin Yaratıcı Doğasına Yönelik Mann Whitney U Testi Bulguları

\begin{tabular}{ccccccc}
\hline & & $N$ & $\begin{array}{c}\text { Sira } \\
\text { ortalamas }\end{array}$ & Sira toplamı & $U$ & $p$ \\
\hline Ön-test & Kontrol grubu & 22 & 25.43 & 559.5 & 306.5 & .969 \\
& Deney grubu & 28 & 25.55 & 715.5 & & \\
\hline \multirow{2}{*}{ Son-test } & Kontrol grubu & 22 & 24.00 & 528.0 & 275.0 & .424 \\
& Deney grubu & 28 & 26.68 & 747.0 & & \\
& & & & & \\
\end{tabular}

\section{Sonuç ve Tartışma}

Araştırma bulguları konu alanı ile ilişkili açık-düşündürücü yaklaşıma dayalı gerçekleştirilen öğretimin dolaylı yaklaşımla gerçekleştirilen öğretime kıyasla öğrencilerin bilimin doğası görüşlerinde anlamlı bir farklılık oluşturmadığını göstermektedir. Buna karşın bulguların bilimin doğası alt boyutlarında çeşitlilik gösterdiği saptanmıştır.

Kontrol grubunda bulunan öğrencilerin büyük kısmı uygulamadan önce bilimi teknoloji ile eşdeğer görürken, daha az sayıda öğrencinin bilimi araştırma süreçleri ve bir bilgi biçimi olarak düşündüğü tespit edilmiştir. Uygulamadan sonra ise bilimi teknoloji ile eşdeğer olarak gören öğrenci sayısında azalma meydana gelse de bu düşüncenin ağırlığını koruduğu, bilimi araştırma ve bilgi olarak gören öğrenci sayısında ise artış meydana geldiği tespit edilmiştir (Bkz. Tablo 7). Deney grubunda ise uygulamadan önce öğrencilerin büyük kısmı bilimin araştırmaya dayalı bir süreç olduğunu düşünürken, önemli sayıda öğrencinin bilimi teknoloji ile eşdeğer gördüğü saptanmıştır. Uygulamadan sonra bilimi teknoloji olarak gören öğrenci sayısında azalmalar meydana geldiği, bilimi araştırma süreci olarak düşünen öğrenci sayısının değişmediği ancak bilimin bir bilgi biçimi olduğunu dile getiren öğrenci sayısında artış olduğu tespit edilmiştir. Araştırmadan elde edilen sonuçlar, öğrencilerin bilim hakkında çeşitli yanılgılara sahip olduğunu ortaya koymaktadır. Öğrencilerin uygulama öncesi ve sonrasında aldıkları puanlara ilişkin istatistiksel analiz sonuçları da gerçekleştirilen öğretimin, öğrencilerin bilimin ampirik doğasına ilişkin görüşlerinde anlamlı bir değişime yol açmadığını göstermektedir ( $U=296.0 ; p>.05)$. Ortaya çıkan bu sonucun gerçekleştirilen etkinliklerde bilimin ampirik yönüne ilişkin bölümlerin yeterince vurgulanamamış olması, canlandırma etkinliğinden sonra biçimlendirmeci değerlendirmenin bilimin ampirik doğasını kavratacak şekilde uygulanamamış olması ile ilişkili olabileceği düşünülmektedir. Bu araştırmanın sonuçları, bilimi keşif, icat, bilimsel araştırma ve bilgi olarak gören ortaokul öğrencileriyle yapılmış çalışmalar ile (Balkı, Çoban, \& Aktaş, 2003; Demir \& Akarsu, 2013) bilimi bir bilgi biçimi, araştırma süreçleri ve doğanın işleyişini anlamak için bir araç olarak gören fen bilgisi öğretmenleri (Aslan, Yalçın, \& Taşar, 2009; Bayır, Çakıcı, \& Ertaş-Atalay, 2016) ile yapılmış çalışmalarla paralellik göstermektedir.

Araştırmada uygulama öncesi ve sonrasında hem kontrol hem de deney gruplarında yer alan öğrencilerin büyük kısmı bilimsel bilginin değişebilir özellikte olduğunu ifade etmişlerdir (Bkz. Tablo 9). Öğrencilerin uygulama öncesinde bilimsel bilgideki değişimi en çok teknolojideki değişimle eşdeğer gördükleri, uygulamadan sonra ise sahip olunan bilgide meydana gelen değişim şeklinde düşündükleri 
belirlenmiştir. Bununla beraber az sayıda öğrencinin bilimsel bilginin değişmeyeceğini dile getirdiği ve yine az sayıda öğrencinin de sorgulanan maddeye ilişkin fikir beyan etmediği tespit edilmiştir. Bu durum her iki gruptaki öğrencilerin bilimsel bilginin değişkenliği boyutunda gerçekçi görüşe sahip olduğunu ortaya koymaktadır. Ayrıca öğrenci yanıtlarının istatistiksel analizi, gerçekleştirilen öğretimin öğrencilerin bilimsel bilginin değişken doğasına yönelik görüşlerinde anlamlı bir fark yarattığını göstermektedir $(\mathrm{U}=214.0 ; p<.05)$. Alanyazın incelendiğinde ortaokul öğrencileri (Ustaoğlu, 2010) ile fen bilgisi ve sınıf öğretmen adaylarının (Yenice ve diğerleri, 2015) bilimin değişken doğasına yönelik gerçekçi görüşe sahip olduklarını gösteren benzer çalışmalara rastlamak mümkündür. Ayrıca öğretim etkinliklerinin ana sınıfı öğrencilerinin ve öğretmen adaylarının bilimsel bilginin değişken doğasına ilişkin görüşlerini geliştirmede etkili bir yol olduğunu gösteren çalışmalar (Akerson \& Donnelly, 2010; Lederman \& O’Malley, 1990; Özbek, 2013) da mevcuttur.

Kontrol ve deney gruplarında yer alan öğrencilerin uygulama öncesinde ve sonrasında bilimin subjektif doğasına yönelik açıklama oluşturmaktan uzak oldukları dikkat çekmiştir. Bu başlık altında kendilerine yöneltilen soruda öğrencilerin önemli kısmının bilimin nesnel yapısına dair herhangi bir fikrinin olmadığı tespit edilmiştir. Bunun yanı sıra fikir beyan eden öğrencilerin bir kısmı bilim insanlarının ulaştığı sonuçların çeşitliliğinin farklı düşünmelerinden kaynaklandığını ifade ederken bir kısmı da yetersiz ön bilgiye sahip olmalarının bilim insanlarını farklı sonuçlara yönlendirdiğini dile getirmiştir (Bkz. Tablo 11). Yürütülen öğretim etkinliklerinden sonra sınırlı sayıda öğrencinin görüşünde değişiklik meydana gelmiştir. Bu öğrenciler sonuçlardaki farklılı̆̆ bilim insanlarının hayal gücü, yaratıcılığı ve verileri yorumlamaları ile ilişkilendirmişlerdir. Alanyazında da bilimsel bilginin elde edilmesi sürecinde bilim insanlarının kişisel özelliklerini çalışmalarına yansıttıklarını düşünen fen bilgisi öğretmenleri ile öğretmen adaylarının olduğunu belirten güncel çalışmalara (Adak \& Bakır, 2017; Önen-Öztürk \& Bayram, 2017) rastlamak mümkündür. Mevcut araştırmada açığa çıkan bu sonuçlar öğrencilerin bilimin subjektif doğası boyutunda yetersiz anlayışa sahip olduklarını gösterir niteliktedir. İstatistiksel analiz sonuçları da gerçekleştirilen öğretimin bilimin subjektif doğası boyutunda anlamlı bir değişim yaratmadığını göstermektedir ( $U=276.0 ; p>.401)$. Benzer biçimde Akerson ve Donnelly (2010) açı-düşündürücü yaklaşım kullanarak gerçekleştirdikleri öğretim sonunda öğrencilerin en az gelişim gösterdikleri bilimin doğası boyutunun subjektiflik olduğunu ifade etmişlerdir. Buna karşın alanyazında ilköğretim öğrencileri (Hastürk ve diğerleri, 2014) ile öğretmen ve öğretmen adaylarının (Akçay, 2011; Erdoğan \& Köseoğlu, 2015) bilim insanlarının objektif olduğunu düşündüğü güncel çalışmalar da bulunmaktadır. Bu boyutta açığa çıkan farklı sonuçların kullanılan ölçme araçları ve çalışma grupları ile ilişkili olduğu düşünülmektedir.

Bilimin yaratıcı doğasına ilişkin görüşler incelendiğinde hem kontrol grubunda hem de deney grubunda uygulamadan önce ve sonra öğrencilerin büyük kısmı bilimde yaratıcılık ve hayal gücü kullanıldığını ifade etmişlerdir (Bkz. Tablo 13). Bu sonuçlar öğrencilerin bilimin yaratıcı doğasına ilişkin gerçekçi görüşe sahip olduklarını ortaya koymaktadır. Bilimin yaratıcı doğası boyutunda ortaokul öğrencilerinin (Çelikdemir, 2006; Demir \& Akarsu, 2012) ve öğretmen adaylarının (Önen-Öztürk \& Bayram, 2017) yeterli görüşe sahip olduğunu saptayan çalışmalar bulunmaktadır. Buna karşın ortaokul öğrencilerinin bilimin yaratıcı doğasına ilişkin görüşlerinin zayıf ya da değişken 
seviyesinde olduğunu gösteren araştırmalar (Demirtel, 2010; Küçük, 2016; Küçük \& Çepni, 2015) da mevcuttur. İstatistiksel analiz sonuçları gerçekleştirilen öğretimin bilimin yaratıcı doğası boyutunda anlamlı bir değişime yol açmadığını göstermektedir $(\mathrm{U}=275.0 ; p>.05)$. Öğrencilerin uygulamadan önce bilimin yaratıcı doğası boyutunda yeterli düzeyde bilgi sahibi olmasının yürütülen etkinliklerin değişime yol açmamasında etkili olduğunu düşünülmektedir. Zira etkinliklerden önce bu boyutta yetersiz veya değişken görüşe sahip olan öğrencilerle gerçekleştirilen öğretim uygulamalarında önemli değişimlerin meydana geldiği tespit edilmiştir (Çelik, 2016; Küçük, 2016).

Açık-düşündürücü yaklaşımla gerçekleştirilen öğretim etkinlikleri ortaokul öğrencilerinin bir bütün olarak bilimin doğası anlayışlarını geliştirmede dolaylı yaklaşımla gerçekleştirilen öğretime göre olumlu değişime yol açsa da anlamlı bir fark yaratamamıştır. Buna neden olarak bazı etkinliklerin uygulama yönergesinin net biçimde anlaşılmaya imkân vermemesi, bazı etkinliklerin uygulanması için sürenin yeterli olmaması ve bu nedenle araştırmacının özellikle drama etkinliklerinde biçimlendirmeye yeterli zaman ayıramaması verilebilir. Buna karşın gerçekleştirilen öğretim etkinlikleri, geliştirmeyi hedeflediği bilimin doğasının dört alt boyutundan biri olan bilimin değişken doğası boyutunda olumlu değişimler gerçekleştirmiştir.

\section{Öneriler}

Literatürde mevcut araştırma sonuçları ile bire bir örtüşme göstermese de bazı aç1lardan benzerlik taşıyan çalışmalara rastlamak mümkündür. Sönmez ve Pektaş (2017) konu alanı dışı etkinlikler kullanarak gerçekleştirdikleri öğretim sonucunda ortaokul öğrencilerinin bilimin doğası anlayışlarının anlamlı bir biçimde değişmesine karşın bu değişimin öğrencilerin tamamında meydana gelmediğini ifade etmişlerdir. Benzer sonuç Demirtel (2010) tarafından yapılan çalışmada da açığa çıkmıştır. Bilimin doğası boyutlarına yapılan vurgunun ve kazandırılmak istenen boyutun özelliklerinin etkinlik sürecinde ön plana çıkarılmasının öğrencilerin bilimin doğası görüşlerinin gelişiminde önemli bir yeri olduğu düşünülmektedir. Bununla beraber bireysel farklılıklar ve uygulamanın yapılacağı sınıfın akademik başarısı gibi değişkenlerin göz önüne alınarak etkinliklerin içeriğinde öğrenci seviyesine uygun değişiklerin yapılmasının bilimin doğası görüşlerinin olumlu yönde geliştirilmesine katk1 sağlayacağı düşünülmektedir. Ayrıca öğrencilerin bilim doğasının bütün boyutlarına yönelik görüşlerini ortaya çıkarmak için yapılacak araştırmalara her bir boyuta vurgu yapan etkinliklerin dâhil edilmesi ve böylece bilimin doğası görüşlerini açığa çıkartabilecek daha uzun süreli ancak daha bütüncül bir bakış açısı yakalanabileceği düşünülmektedir. Araştırmanın yapıldığı gruptan elde edilen sonuçların belli bir zaman dilimi içinde belli bir bölgede öğrenim gören öğrencilerin bilimin doğası görüşleri hakkında fikir verdiği düşünüldüğünde, ilgili konu üzerinde öğrenci görüşlerinin farklı bölgelerde öğrenim gören öğrencileri de içine alacak şekilde genişletilmesi önerilmektedir. Bununla birlikte Fen Bilimleri Dersi Öğretim Programı'nın değiştiği göz önüne alındığında uygulanan bilimin doğası etkinliklerinin içeriklerinin yenilenen kazanımlara ve sınıf seviyelerine uyumlu hale getirilerek araştırma sürecinin planlanması önerilmektedir. Gelecekte benzer çalışmalar yapacak araştırmacıların yukarıda bahsi geçen değişiklikleri göz önünde bulundurmaları önerilmektedir. 


\section{Summary}

Purpose and Significance: In recent years, published documents on science education reform movements have focused on scientific literacy as the main objective (NGSS Lead States, 2013; NRC, 1996; MoNE, 2017). Although the perspectives are different from each other, the strong emphasis on the nature of science in the proposals for reforms draws attention (Lederman, 1999). Although there is no consensus on the definition of nature of science, it is possible to talk about a compromise in its dimensions (McComas \& Olson, 2002). Gaining an adequate understanding of the dimensions of the nature of science can be seen as a prerequisite for educating scientifically literate individuals. In order to develop this kind of comprehension, it is necessary to teach the nature of science effectively. Approaches for teaching the nature of science are basically classified as explicit and implicit approaches (Abd-El-Khalick $\&$ Lederman, 2000a). Over time, researches on the teaching nature of science have begun to be shaped around the question of which approach is more effective. A significant part of the investigations reveals that the explicit-reflective approach is an effective approach to teaching the nature of science (Abd-El-Khalick, 2005; Ağlarc1, Sarıçayır, \& Şahin, 2016; Erdoğan \& Köseoğlu, 2015; Khishfe \& Lederman, 2006; Koenig, Schen, \& Bao, 2012; Önen-Öztürk, 2015; Wong, Firestone, Ronduen, \& Bang, 2016). An important part of the nature of science researches fulfilled in Turkey was carried out with prospective teachers (Çelik, 2015; Erdoğan \& Köseoğlu, 2015; ÖnenÖztürk \& Bayram, 2017). In the researches carried out with middle school students, it was tried to develop the students' nature of science views through independent teaching strategies from the subject field (Çokadar \& Demirtel, 2012). For this reason, it is considered necessary to implement activities that use an explicit-reflective approach related to the subject area. Thus, it is aimed to reveal the students' nature of science views and determine the effect of teaching activities integrated in the subject area with explicit-reflective approach on these views.

Method: In this research, pretest - posttest control group experimental design was used. The study was carried out with 50 students who were 6th grade in a public middle school in Istanbul during the fall semester of 2017-2018 academic years. The VNOS-D + form, which was developed by Lederman and Khishfe (2002) consists of 10 openended questions, has been used to determine students' nature of science views and the changes in these views within the teaching process. The research was carried out for 24 hours period, designed in the context of the cell, muscular \& skeletal system and vascular system topics in the "Systems in our Body" unit at the 6th grade science class. Explicit-reflective approach was used for the experimental group and implicit approach was used for the control group. In the study, activities called "I see!", "Röntgen (X-Ray) of life" and "From Galen to Harvey as a film" developed by Yalaki (2016) for middle school students were used. Analysis of the research data were carried out in two stages, data obtained in the first stage were analysed by content analysis. Students' responses about empirical, tentative, subjective and creative nature of science were coded. Afterwards, similar coding was presented as a table with the frequency of response under these categories. In the second stage, rubric adapted to Turkish by Yalaki and Çakmakçı (2011) used. Students' responses were classified as "naïve", "have merit" and "informed". The obtained data were coded with scores and subjected to statistical 
analysis. Mann Whitney U test was used to assess the efficacy of the teaching process, which has non-parametric data.

Results: At the end of the teaching activities in the research process, no statistically meaningful difference was found between the experimental group and the control group students' views of the nature of the science. However, the results of the research vary in the dimensions of the nature of science.

When student views on the empirical nature of science are examined, the students in the control group consider science as technology, a research process and a form of knowledge. After the teaching activities, the control group opinions about science concentrated on the same categories. Before the teaching activities, the students in the experimental group stated that science is a research process, technology and knowledge. After the teaching activities, the answers were concentrated in the same categories but the decrease in the number of students who regarded science as being equivalent to the technology and the increase in the number of students who regarded science as the information were revealed. As a result of the statistical analysis, it was found that the teaching practices which are realized with an explicit-reflective approach did not cause a meaningful difference in students' views about the empirical nature of science $(\mathrm{U}=$ 296.0, $p>.05)$.

When the results of research on the tentative nature of science are examined, most of the students in the control group think that scientific knowledge can change before the teaching process, and the majority of these students consider scientific knowledge change as a change in technology. After the practice, the majority of students expressed that scientific knowledge could change. In addition, the number of students who thought scientific knowledge change as a change in technology increased. Similarly, before the teaching activities most of the students in the experimental group also stated that scientific knowledge could change and this change was mainly a change in technology. After the teaching activities number of students, who indicate that scientific knowledge changed increased. On the other hand, the number of students who think scientific knowledge change as a change in technology decreased and the number of students who think scientific knowledge change as a change in knowledge increased. As a result of the statistical analysis, it was found that the activities cause a meaningful difference in their views about the tentative nature of science $(\mathrm{U}=214.0, p<.05)$.

When students' views on the subjective nature of science were examined, it was determined that most of the students in the control and experimental groups did not express their views about the subjective nature of science, both before and after the teaching activities. The students in the control group both pretest and posttest showed that, scientists had different thoughts, insufficient preliminary knowledge, or different prior knowledge as justification for reaching different results with the same research data. Before teaching process in the experiment group, a significant part of the students explained that the scientists reach the different results with the same research data due to a different view, insufficient preliminary knowledge and the excess of probable causes. After the teaching activities, while the number of students who did not submit an opinion on the subject increased the students explained the difference of the research results with the most inadequate prior knowledge and different thinking process. It was 
found that the teaching activities did not lead to a statistically meaningful difference in students' views about subjective nature of science $(\mathrm{U}=276.0, p>.05)$.

The overwhelming majority of both the control group and the experimental group students, before and after the teaching activities, stated that scientists use their imagination and creativity in their research. It is possible to say that students have a realistic view on the creative nature of science. On the other hand, the activities conducted did not make a statistically meaningful difference in the views of students on the creative nature of science $(\mathrm{U}=275.0, p>.05)$.

Discussion and Conclusions: The results of the research show that the activities based on explicit-reflective approach do not make a meaningful difference in the students' nature of science views compared to teaching conducted by the implicit approach. On the other hand, the results are diverse in the dimensions of the nature of science. When the findings belonging to the dimension of empirical nature of science were examined, most of the students thought science as technology, a knowledge format and the research process. These results are in parallel with the studies carried out with secondary school students (Balk1, Çoban, \& Aktaş, 2003; Demir \& Akarsu, 2013) and the science teachers (Aslan, Yalçın, \& Taşar, 2009; Bayır, Çakıcı, \& Ertaş-Atalay, 2016) who think science as exploration, invention, scientific research and knowledge. It has been determined that those students have a realistic view on the tentative nature of science. There are studies showing that middle school students (Ustaoğlu, 2010), science and classroom pre-service teachers (Yenice et al., 2015) have a realistic view at this dimension. It has also been determined that the teaching process leads to a meaningful difference in the tentative nature of science. This result is consistent with studies showing that the views of the kindergarten students and prospective teachers who joined teaching activities have improved (Akerson \& Donnelly, 2010; Lederman \& O’Malley, 1990; Özbek, 2013). In this research, it has been determined that most of the students do not have an idea on the subjective nature of science. It was realized that teaching process did not make any meaningful difference at this dimension. Akerson and Donnelly (2010) stated in their study that, students' views developed least in the subjective nature of science. Moreover, studies in the literature show that students and teacher candidates think that scientists are objective (Akçay, 2011; Erdoğan \& Köseoğlu, 2015; Hastürk et al., 2014). In the creative nature of science, it has been determined that students have realistic views. This result is consistent with some studies in the literature (Çelikdemir, 2006; Demir \& Akarsu, 2012; Önen-Öztürk \& Bayram, 2017). On the other hand, some studies also show that students have either naïve or have an unsteady view's (Demirtel, 2010; Küçük, 2016; Küçük \& Çepni, 2015). We think that the implementation guidelines of some activities do not allow a clear understanding and that the lack of time is an important factor in decreasing the effectiveness of implementation. For this reason, we propose that the future researchers, in addition to regulating the above factors, increase the emphasis on the dimension nature of the science to be acquired and organize the activities according to the academic achievement level of the class. 


\section{Kaynaklar}

Abd-El-Khalick, F. (2005). Developing deeper understandings of nature of science: The impact of a philosophy of science course on preservice science teachers' views and instructional planning. International Journal Science Education, 27(1), 15-42. doi: 10.1080/09500690410001673810

Abd-El-Khalick, F., \& Akerson, V. L. (2004). Learning as conceptual change: Factors mediating the development of preservice elementary teachers' views of nature of science. Science Education, 88(5), 785-810. doi:10.1002/sce.10143

Abd-El-Khalick, F., \& Lederman, N. G. (2000a). Improving science teachers' conceptions of nature of science: A critical review of the literature. International Journal of Science Education, 22(7), 665-701. doi: 10.1080/09500690050044044

Abd-El Khalick, F., \& Lederman, N. G. (2000b). The influence of history of science courses on students' views of nature of science. Journal of Research in Science Teaching, 37(10), 295-317. doi:10.1002/1098-2736(200012)37:10<1057::AIDTEA3>3.0.CO;2-C

Adak, F., \& Bakır, S. (2017). Fen bilimleri öğretmenleri ve öğretmen adaylarının gözüyle bilimin doğası. Çukurova Üniversitesi Eğitim Fakültesi Dergisi, 46(2), 472-503. doi: 10.14812/cuefd.273857

Adibelli-Şahin, E., \& Deniz, H. (2017). Elementary teachers' perceptions about the effective features of explicit-reflective natüre of science instruction. International Journal of Science Education, 39(6), 761-790. doi: 10.1080/09500693.2017.1308035

Ağlarcı, O. (2014). Doğrudan-yansıtıcı yaklaşıma dayalı öğretimin kimya öğretmen adaylarının bilimin doğası görüşlerine etkisi (Yayımlanmamış doktora tezi). Marmara Üniversitesi, İstanbul, Türkiye.

Ağlarcı, O., Sarıçayır, H., \& Şahin, M. (2016). Nature of science instruction to Turkish prospective chemistry teachers: The effect of explicit-reflective approach. Cogent Education, 3(1), 1-19. doi: 10.1080/2331186X.2016.1213350

Akçay, B. (2011, June). Turkish elementary and secondary students' views about science and scientist. Paper published in the proceedings of the Asia-Pacific Forum on Science Learning and Teaching, 12(1), 11.

Akerson, V. L., \& Donnelly, L. A. (2010). Teaching nature of science to K-2 students: What understandings can they attain? International Journal of Science Education, 32(1), 97-124. doi: 10.1080/09500690902717283

Akindehin, F. (1988), Effect of an instructional package on preservice science teachers' understanding of the nature of science and acquisition of science-related attitudes. Science Education, 72(1), 73-82. doi:10.1002/sce.3730720107

Albayrak, A. S. (2009). Çok değişkenli istatistik tekniklerinin varsayımları. In Ş. Kalaycı (Ed.) SPSS uygulamalı çok değişkenli istatistik teknikleri. (4. Baskı) (s. 207-230). Ankara: Asil Yayın Dağıtım.

American Association for the Advancement of Science [AAAS] (1990). Science for all Americans. New York: Oxford University Press.

Aslan, O., \& Taşar, M. F. (2013). How do science teachers view and teach nature of science? A classroom investigation. Education \& Science, 38(167), 65-80. 
Aslan, O., Yalçın, N., \& Taşar, M. F. (2009). Fen ve teknoloji öğretmenlerinin bilimin doğası hakkındaki görüşleri. Ahi Evran Üniversitesi Ĕ̆itim Fakültesi Dergisi, 10(3), 1-8.

Ayvacı, H. Ş. (2007). Bilimin doğasının sınıf öğretmeni adaylarına kütle çekim konusu içerisinde farklı yaklaşımlarla ögretilmesine yönelik bir çalışma (Yayımlanmamış doktora tezi). Karadeniz Teknik Üniversitesi, Trabzon, Türkiye.

Bala, V. G. (2013). Bilimin doğasının fen konularına entegrasyonunda biçimlendirici değerlendirme uygulamalarının bilimin doğası ögrenimine etkisi (Yayımlanmamış yüksek lisans tezi). Hacettepe Üniversitesi, Ankara, Türkiye.

Balkı, N., Çoban, A. K., \& Aktaş, M. (2003). İlköğretim öğrencilerinin bilim ve bilim insanına yönelik düşünceleri. Uludă̆ Üniversitesi Eğitim Fakültesi Dergisi, 16(1), 11-17.

Barab, S. A., \& Hay, K. E. (2001), Doing science at the elbows of experts: Issues related to the science apprenticeship camp. Journal of Research in Science Teaching, 38(1), 70-102. doi:10.1002/1098-2736(200101)38:1<70::AIDTEA5>3.0.CO;2-L

Bayır, E., Çakıcı, Y., \& Ertaş-Atalay, Ö. (2016). Fen bilimleri öğretmenlerinin bilimin doğasına ilişkin görüşleri: Bilişsel harita örneği. Kastamonu Üniversitesi Kastamonu Ë̆itim Dergisi, 24(3), 1419-1436.

Bell, R. L., Blair, L. M., Crawford, B. A., \& Lederman, N. G. (2003). Just do it? impact of a science apprenticeship program on high school students' understandings of the nature of science and scientific inquiry. Journal of Research in Science Teaching, 40(5), 487-509. doi:10.1002/tea.10086

Büyüköztürk, Ş., Çakmak, E. K., Akgün, Ö. E., Karadeniz, Ş., \& Demirel, F. (2009). Bilimsel araştırma yöntemleri (5. Baskı). Ankara: Pegem Akademi.

Cengiz, C., \& Kabapınar, F. (2017). Dolaylı fen öğretiminde hizmet öncesi argümantasyon eğitiminin öğretmen adaylarının bilimin doğasını kavramalarına etkisi. Türkiye Kimya Derneği Dergisi Kısım C: Kimya Ĕ̆itimi, 2(1), 19-62.

Central Association for Science and Mathematics Teachers (CASMT) (1909). A consideration of the principles that should determine the courses in biology in secondary schools. School Science and Mathematics, 9(3), 241-247. doi: 10.1111/j.1949-8594.1909.tb03028.x

Council of Ministers of Education, Canada (CMEC) Pan-Canadian Science Project. (1997). Common framework of science learning outcomes $K$ to 12 . Retrieved from http://204.225.6.243/science/framework/

Çakırlar-Altuntaş, E., Yılmaz, M., \& Turan, S. L. (2017). Biyoloji öğretmen adaylarının sosyobilimsel bir konudaki eleştirel düşünmelerinin empati açısından incelenmesi. Bartın Üniversitesi Eğitim Fakültesi Dergisi, 6(3), 915-931. doi: 10.14686/buefad.307420

Çelik, S. (2015). Açık ve yansıtıcı yaklaşımla bilimin doğası öğretiminin lisansüstü öğrencilerinin bilimin doğası anlayışlarına etkisi. Kazım Karabekir Ĕgitim Fakültesi Dergisi, 31, 125-147. 
Çelik, S. (2016). Sekizinci sınıf öğrencilerinin bilimin doğasına yönelik anlayışlarının geliştirilmesinde kavram karikatürü kullanımı (Yayımlanmamış yüksek lisans tezi). Balıkesir Üniversitesi, Balıkesir, Türkiye.

Çelikdemir, M. (2006). Examining middle school students'understanding of the nature of science (Unpublished doctoral dissertation). Middle East Technical University, Ankara, Turkey.

Çetinkaya, E. (2012). Bilim sözde-bilim ayrımı tartışmasının ortaokul 8. sınıf ögrencilerinin bilimsellik algıları ve akademik bilgi düzeylerine etkisi (Yayımlanmamış yüksek lisans tezi). Marmara Üniversitesi, İstanbul, Türkiye.

Çetinkaya, E. (2017). Bilim sözde-bilim ayrımı bă̆lamında tasarlanan argümantasyon odakl etkinliklerin, ortaokul ögrrencilerinin bilimin doğası görüşlerine, sözdebilimsel inanışlarına ve argümantasyon becerilerine etkisi (Yayımlanmamış doktora tezi). Gazi Üniversitesi, Ankara, Türkiye.

Çıngı, H. (1994). Örnekleme Kuramı. Ankara: Hacettepe Üniversitesi Basımevi.

Çil, E., \& Çepni, S. (2016). Kavramsal değişim yaklaşımının bilimin doğası hakkındaki görüşler ve 1şı ünitesindeki akademik başarı üzerine etkileri. Hacettepe Üniversitesi Ĕ̌itim Fakültesi Dergisi, 31(1), 82-96. doi: 10.16986/HUJE.2015014184

Çokadar, H., \& Demirtel, Ş. (2012). Doğrudan yansitıcı etkinliklerle öğretimin öğrencilerin bilimin doğası anlayışlarına ve fene yönelik tutumlarına etkisi. Pamukkale Üniversitesi Eğitim Fakültesi Dergisi, 31, 67-79.

Demir, N., \& Akarsu, B. (2012). Ortaokul öğrencilerinin bilimin doğası hakkındaki alg1lar1. Journal of European Education, 2(2), 1-9 doi: 10.18656/JEE.88838

Demirtel, Ş. (2010). Bilimin doğası etkinliklerinin ilköğretim sekizinci sınıf öğrencilerinin bilimin doğası anlayışlarına etkisi (Yayımlanmamış yüksek lisans tezi). Pamukkale Üniversitesi, Denizli, Türkiye.

Dickinson, V. L., Abd-El-Khalick, F., \& Lederman, N. G. (2000). Changing elementary teachers' views of the NOS: Effective strategies for science methods courses. ERIC Document Reproduction Service No. ED 441680

Doğanay, A., Demircioğlu, T., \& Yeşilpınar, M. (2014). Öğretmen adaylarına yönelik bilimin doğası konulu disiplinler arası öğretim programı geliştirmeye ilişkin bir ihtiyaç analizi çalışması. Turkish Studies, 9(5), 777-798. doi: 10.7827/TurkishStudies.6725

Erdoğan, M. N., \& Köseoğlu, F. (2015). Kimyasal denge konusuna entegre edilmiş açık-düşündürücü yaklaşımla bilimin doğası öğretimi. Eğitimde Kuram ve Uygulama, 11(2), 717-741. doi: 10.17244/eku.10274

Fouad, K. E., Masters, H., \& Akerson, V. (2015). Using history of science to teach nature of science elementary students. Science \& Education, 24(9-10), 1103-1140. doi: 10.1007/s11191-015-9783-5

Fraenkel, J. R., Wallen, N. E., \& Hyun, H. H. (2011). How to design and evaluate research in education ( $8^{\text {th }}$ edition). McGraw-Hill: New York.

Gess-Newsome, J. (2002). The use and impact of explicit instruction about the nature of science and science inquiry in an elementary science methods course. Science \& Education, 11(1), 55-67. doi: 10.1023/A:1013054823482 
Göksu, V., Aslan, O., Özel, M., \& Şenel-Zor, T. (2016). Açık-düşündürücü ve tarih temelli öğretimin fen bilimleri öğretmen adaylarının bilimin doğası anlayışları üzerindeki etkisi. Mustafa Kemal Üniversitesi Sosyal Bilimler Enstitüsü Dergisi, 13(34), 313-327.

Hastürk, H. G., Öztürk, N., Demir, R., \& Kartal, T. (2014). Farklı eğitim kademelerinde öğrenim gören öğrencilerin bilimin doğası ile ilgili görüşleri. Tarih Okulu Dergisi, 7(18), 671-688. doi: 10.14225/Joh479

Herman, B. C. (2010). Teaching the nature of science: Practices and associated factors (Unpublished doctoral dissertation). Iowa State University, Iowa, USA.

İflazoğlu-Saban, A., \& Saban, A. (2014). Sınıf öğretmenliği öğrencilerinin bilimin doğası hakkındaki görüşlerinin cinsiyet ve sınıf düzeyine göre incelenmesi. Gaziantep University Journal of Social Sciences, 13(4), 1121-1135. doi: $10.21547 /$ jss. 257188

Kalaycı, Ş. (2009). SPSS uygulamalı çok değişkenli istatistik teknikleri. (4. Baskı). Ankara: Asil Yayın Dağıtım.

Kang, S., Scharmann, L. C., Noh, T., \& Koh, H. (2005). The influence of students' cognitive and motivational variables in respect of cognitive conflict and conceptual change. International Journal of Science Education, 27(9), 1037-1058. doi: 10.1080/09500690500038553

Karakaş, M. (2017). Turkish students' views on nature of science. European Journal of Education Studies, 3(10), 176-183. doi: 10.5281/zenodo.996074

Kılıç, S. (2015). Kappa testi. Journal of Mood Disorders, 5(3), 142-144. doi: 10.5455/jmood.20150920115439

Khishfe, R. (2008). The development of seventh graders' views of nature of science. Journal of Research in Science Teaching, 45(4), 470-496. doi:10.1002/tea.20230

Khishfe, R. (2015). A look into students' retention of acquired nature of science understandings. International Journal of Science Education, 37, 1639-1667. doi: 10.1080/09500693.2015.1049241

Khishfe, R., \& Abd-El-Khalick, F. (2002). Influence of explicit and reflective versus implicit inquiry-oriented instruction on sixth graders' views of nature of science. Journal of Research in Science Teaching, 39(7), 551-578. doi:10.1002/tea.10036

Khishfe, R., \& Lederman, N. (2006). Teaching nature of science within a controversial topic: Integrated versus nonintegrated. Journal of Research in Science Teaching, 43(4) 395-418. doi:10.1002/tea.20137

Koenig, K., Schen, M., \& Bao, L. (2012). Explicitly targeting pre-service teacher scientific reasoning abilities and understanding of nature of science through an introductory science course. Science Educator, 21(2), 1-9.

Köseoğlu, F., Tümay, H., \& Budak, E. (2008). Bilimin doğası hakkında paradigma değişimleri ve öğretimi ile ilgili yeni anlayışlar. Gazi Eğitim Fakültesi Dergisi, 28(2), 221-237.

Kutlu, H., Doğan, C. D., \& Karakaya, İ. (2009). Öğrenci başarısının belirlenmesi performansa ve portfolyoya dayalı durum belirleme. Ankara: Pegem Akademi. 
Küçük, A. (2016). Işık konu alanı içinde ve dışında bilimin doğası öğretiminin 5. sınıf ögrencilerinin bilimin doğasına yönelik anlayışlarına etkisi (Yayımlanmamış yüksek lisans tezi). Recep Tayyip Erdoğan Üniversitesi, Rize, Türkiye.

Küçük, M. (2006). Bilimin doğasını ilköğretim 7. sınıf öğrencilerine öğretmeye yönelik bir çalışma (Yayımlanmamış doktora tezi). Karadeniz Teknik Üniversitesi, Trabzon, Türkiye.

Küçük, M. (2008). Improving preservice elementary teachers' views of the nature of science using explicit-reflective teaching in a science, technology and society course. Australian Journal of Teacher Education, 33(2). 16-40. doi: 10.14221/ajte.2008v33n2.1

Küçük, M., \& Çepni, S. (2015). A qualitative study to explain middle school student's understandings of nature of science. Journal of Turkish Science Education, 12(3), 3-20. doi: 10.12973/tused.10143a

Lederman, N. G. (1992). Students' and teachers' conceptions of the nature of science: A review of the research. Journal of Research in Science Teaching, 29(4), 331- 359. doi: 10.1002/tea.3660290404

Lederman, N. G. (1998). The state of science education: Subject matter without context. Electronic Journal of Science Education, 3(2). Retrieved from http://ejse.southwestern.edu/article/view/7602/5369

Lederman, N. G. (1999). Teachers' understanding of the nature of science and classroom practice: Factors that facilitate or impede the relationship. Journal of Research in Science Teaching, 36(8), 916-929. doi:10.1002/(SICI)10982736(199910)36:8<916::AID-TEA2>3.0.CO;2-A

Lederman, N. G. (2007). Nature of science: Past, present, and future. In S. K. Abel \& N. G. Lederman (Eds.), Handbook of research on science education (pp. 831879). Mahwah, NJ: Erlbaum.

Lederman, J. S., \& Khishfe, R. (2002). Views of nature of science, Form D. Unpublished paper. Chicago: Illinois Institute of Technology, Chicago, IL.

Lederman, N. G., \& O'Malley, M. (1990). Students' perceptions of tentativeness in science: Development, use, and sources of change. Science Education, 74(2), 225239. doi: $10.1002 /$ sce. 3730740207

Liu, S.-Y., \& Lederman, N. G. (2002). Taiwanese gifted students' views of nature of science. School Science and Mathematics, 102(3), 114-123. doi:10.1111/j.19498594.2002.tb17905.x

McComas, W. F., \& Olson, J. K. (2002). The nature of science in international science education standart documents. In W. F. Mccomas, (Ed.), The Nature of Science in Science Education: Rationales and Strategies (pp. 41-52). Dordrecht, The Netherlands: Kluwer Academic Publishers. doi: 10.1007/0-306-47215-5

Morrison, J. A., Raab, F., \& Ingram, D. (2009). Factors influencing elementary and secondary teachers' views on the nature of science. Journal of Research in Science Teaching, 46(4), 384-403. doi:10.1002/tea.20252

Milli Eğitim Bakanlığı (MEB) (2017). Fen bilimleri dersi öğretim programı, (İlkokul ve ortaokul 3, 4, 5, 6, 7 ve 8. sinıflar). Ankara: Milli Eğitim Basımevi. 
National Research Council [NRC] (1996). National science education standards. Washington, DC: National Academic Press.

National Research Council [NRC] (2012). A framework for K-12 science education: Practices, crosscutting concepts, and core ideas. Washington, D.C.: The National Academies.

NGSS Lead States. (2013). Next generation science standards: For states, By States. Washington, DC: National Academies Press. Retrieved from http://www.nextgenscience.org/states

Önen-Öztürk, F. (2015). Bilimin doğası öğretimi fen bilgisi öğretmen adaylarının bilimsel araştırmanın doğasına ilişkin görüşlerini nasıl etkiler? The Journal of Academic Social Science Studies, 31, 287-309. doi: 10.9761/JASSS2585

Önen-Öztürk, F., \& Bayram, H. (2017). İki farklı yaklaşıma dayalı bilimin doğası öğretiminin fen bilgisi öğretmen adaylarının kavram yanılgılarının giderilmesindeki etkisi. Marmara Üniversitesi Atatürk Ĕ̈itim Fakültesi Eğitim Bilimleri Dergisi, 45, 115-136. doi: 10.15285/maruaebd.308619

Özden, M., \& Cavlazoğlu, B. (2015). İlköğretim fen dersi öğretim programlarında bilimin doğası: 2005 ve 2013 programlarının incelenmesi. Eğitimde Nitel Araştırmalar Dergisi, 3(2), 40-65. doi: 10.14689/issn.2148-2624.1.3c2s3m+

Özbek, D. (2013). Fen teknoloji toplum dersi kapsamında yapllan uygulamaların ögretmen adaylarının bilimin doğası unsurlarını algılama düzeylerindeki değişime etkisinin incelenmesi (Yayımlanmamış yüksek lisans tezi). Karadeniz Teknik Üniversitesi, Trabzon, Türkiye.

Özden, B., \& Yenice, N. (2016). Fen bilgisi öğretmen adaylarının bilimsel kanun ve teori kavramlarına yönelik görüşleri: Nitel bir durum çalışması. İlköğretim Online, 15(4), 1090-1113. doi: 10.17051/io.2016.98302

Özgelen, S. (2010). Exploring the development of pre-service science teachers' views on nature of science in inquiry-based laboratory instruction (Unpublished doctoral dissertation). Middle East Technical University, Ankara, Turkey.

Piaget, J. (2006). The stages of intellectual development of the child. In Marlowe, B. A. \& Canestrari, A. S. (Eds.), Educational psychology in context, Readings for future teachers (pp. 98-106). Thousand Oaks: Sage Publications.

Ryder, J., Leach, J., \& Driver, R. (1999). Undergraduate science students' images of science. Journal of Research in Science Teaching, 36(2), 201-219. doi:10.1002/(SICI)1098-2736(199902)36:2<201:AID-TEA6>3.0.CO;2-H

Salter, I., \& Atkins, L. (2013). Student-generated scientific inquiry for elementary education undergraduates: Course development, outcomes and implications. Journal of Science Teacher Education,24(1), 157-177. doi: 10.1007/s10972-011-9250-3

Schwartz, R. S., \& Crawford, B. A. (2006). Authentic scientific inquiry as context for teaching nature of science: Identifying critical elements for success. In Flick, L. B. \& Lederman, N. G. (Eds.), Scientific inquiry and nature of science (pp. 331-356). Dordrecht, The Netherlands: Springer. doi: 10.1007/978-1-4020-5814-1

Sönmez, E., \& Pektaş, M. (2017). Ortaokul öğrencilerine müfredat dişında uygulanan bazı biyoteknoloji etkinliklerinin bilimin doğası görüşleri ve biyoteknoloji 
bilgilerine etkisi. Kastamonu Üniversitesi Kastamonu Ĕ̆itim Dergisi, 25(5), 20192036.

Şardağ, M., Aydın, S., Kalender, N., Tortumlu, S., Çiftçi, M., \& Perihanoğlu, Ş. (2014). Bilimin doğasının ortaöğretim fizik, kimya ve biyoloji yeni öğretim programlarında yansitılması. Eğitim ve Bilim, 39(174), 233-248. doi: 10.15390/EB.2014.3069

Ustaoğlu, M. T. (2010). İlköğretim ikinci kademe 7. sinıf öğrencilerinin bilimin doğası ile ilgili bilgi düzeylerinin belirlenmesi (Yayımlanmamış yüksek lisans tezi). Ondokuz Mayıs Üniversitesi, Samsun, Turkey.

Walls, L. (2012). Third grade African American students' views of the nature of science. Journal of Research in Science Teaching, 49(1), 1-37. doi:10.1002/tea.20450

Wong, S. S., Firestone, J. B., Ronduen, L. G., \& Bang, E. J. (2016). Middle school science and mathematics teachers' conceptions of the nature of science: A one-year study on the effects of explicit and reflective online instruction. International Journal of Research in Education and Science (IJRES), 2(2), 469-482. doi: 10.21890/ijres.56557

Yacoubian, H. A., \& BouJaoude, S. (2010). The effect of reflective discussions following inquiry-based laboratory activities on students' views of nature of science. Journal of Research in Science Teaching, 47(10), 1229-1252. doi:10.1002/tea.20380

Yalaki, Y. (2016). Etkinliklerle bilimin doğasının ögrretimi. 5. 6. 7. ve 8. sinıflar. (Genişletilmiş 2. Baskı). Ankara: Pegem Akademi.

Yalaki, Y., \& Çakmakçı, G. (2011, July). Formative assessment to enhance student's learning of nature of science. Paper published in the proceedings of the $11^{\text {th }}$ International History, Philosophy and Science Teaching Conference. Aristotle University of Thessaloniki, Thessaloniki, Greece.

Yenice, N., Özden, B., \& Balcı, C. (2015). Fen bilgisi ve sınıf öğretmen adaylarının bilimin doğasına yönelik görüşlerinin incelenmesi. Erzincan Üniversitesi Ĕ̈itim Fakültesi Dergisi, 17(1), 237-281. doi: 10.17556/jef.52022

Yücel-Dağ, M. (2015). Kavram karikatürleriyle zenginleştirilmiş etkileşimli kısa tarihsel hikâyelerin bilimin doğası ögretiminde kullanımı üzerine bir öz-inceleme (Yayımlanmamış doktora tezi). Gazi Üniversitesi, Ankara, Türkiye.

This is an Open Access article distributed under the terms of the Creative CommonsAttributionNonCommercial-ShareAlike 4.0 International (CC BY-NC-SA 4.0). For further information, you can refer to https://creativecommons.org/licenses/by-nc-sa/4.0/ 